\title{
A 3.7 kb Fragment of the Mouse Scn10a Gene Promoter Directs Neural Crest But Not Placodal Lineage EGFP Expression in a Transgenic Animal
}

\author{
남 Ban Bu, Stephen R. Ikeda, and Henry L. Puhl III \\ Section on Transmitter Signaling, Laboratory of Molecular Physiology, National Institute on Alcohol Abuse and Alcoholism, National Institutes of Health, \\ Bethesda, Maryland 20892-9411
}

\begin{abstract}
Under physiological conditions, the voltage-gated sodium channel $\mathrm{Na}_{\mathrm{v}} 1.8$ is expressed almost exclusively in primary sensory neurons. The mechanism restricting $\mathrm{Na}_{\mathrm{v}} 1.8$ expression is not entirely clear, but we have previously described a $3.7 \mathrm{~kb}$ fragment of the $\mathrm{Scn} 10 \mathrm{a}$ promoter capable of recapitulating the tissue-specific expression of $\mathrm{Na}_{\mathrm{v}} 1.8$ in transfected neurons and cell lines (Puhl and Ikeda, 2008). To validate these studies in vivo, a transgenic mouse encoding EGFP under the control of this putative sensory neuron specific promoter was generated and characterized in this study. Approximately 45\% of dorsal root ganglion neurons of transgenic mice were EGFPpositive $($ mean diameter $=26.5 \mu \mathrm{m})$. The majority of EGFP-positive neurons bound isolectin B4, although a small percentage $(\sim 10 \%)$ colabeled with markers of A-fiber neurons. EGFP expression correlated well with the presence of $\mathrm{Na}_{\mathrm{v}} 1.8 \mathrm{transcript}(95 \%)$, $\mathrm{Na}_{\mathrm{v}} 1.8$ immunoreactivity (70\%), and TTX-R $I_{N a}(100 \%)$, although not all $\mathrm{Na}_{\mathrm{v}} 1.8$-expressing neurons expressed EGFP. Several cranial sensory ganglia originating from neurogenic placodes, such as the nodose ganglion, failed to express EGFP, suggesting that additional regulatory elements dictate Scn10a expression in placodal-derived sensory neurons. EGFP was also detected in discrete brain regions of transgenic mice. Quantitative PCR and $\mathrm{Na}_{\mathrm{v}} 1.8$-immunoreactivity confirmed $\mathrm{Na}_{\mathrm{v}} 1.8$ expression in the amygdala, brainstem, globus pallidus, lateral and paraventricular hypothalamus, and olfactory tubercle. TTX-R $I_{N a}$ recorded from EGFP-positive hypothalamic neurons demonstrate the usefulness of this transgenic line to study novel roles of $\mathrm{Na}_{\mathrm{v}} 1.8$ beyond sensory neurons. Overall, Scn10a-EGFP transgenic mice recapitulate the majority of the $\mathrm{Na}_{\mathrm{v}} 1.8$ expression pattern in neural crest-derived sensory neurons.
\end{abstract}

Key words: dorsal root ganglia; nodose ganglion; pain; sodium channels; transgenic

\section{Introduction}

Voltage-gated sodium channels (VGSCs) are largely responsible for generating and propagating action potentials in neurons and other excitable cells. The pore-forming $\alpha$ subunit of VGSC, which is $\sim 260 \mathrm{kDa}$ in mass, consists of four domains each composed of six transmembrane helices (Catterall, 2000). Nine members of the mammalian $\alpha$ subunit $\left(\mathrm{Na}_{\mathrm{v}} 1.1-1.9\right)$ and four auxiliary $\beta$ subunits $(\beta 1-4)$ have been identified.

The expression profile of the various $\alpha$ subunit family members often overlaps, although some members are expressed exclu-

Received Jan. 15, 2015; revised April 17, 2015; accepted April 22, 2015.

Author contributions: V.B.L. and H.L.P. designed research; V.B.L., S.R.I., and H.L.P. performed research; S.R.I contributed unpublished reagents/analytic tools; V.B.L. and H.L.P. analyzed data; V.B.L., S.R.I., and H.L.P. wrote the paper.

This work was supported by the Intramural program at the National Institutes of Health, National Institute on Alcohol Abuse and Alcoholism. We thank Dr. James Pickel (National Institute of Mental Health Transgenic Core Facility) for assistance with pronuclear microinjections and Dr. Margaret Davis (Laboratory for Integrative Neuroscience/National Institute on Alcohol Abuse and Alcoholism) for technical assistance with immunohistochemistry experiments.

The authors declare no competing financial interests.

Correspondence should be addressed to Dr. Henry L. Puhl, III, Laboratory of Molecular Physiology, National Institutes of Health/National Institute on Alcohol Abuse and Alcoholism, 5625 Fishers Lane, Room TS-06, Rockville, MD 20852. E-mail: puhlh@mail.nih.gov.

DOI:10.1523/JNEUROSCI.0214-15.2015

Copyright $\odot 2015$ the authors $\quad 0270-6474 / 15 / 358021-14 \$ 15.00 / 0$ sively in discrete locations. For instance, $\mathrm{Na}_{\mathrm{v}} 1.8$ is expressed in a subset of primary afferent neurons of which $>85 \%$ are nociceptors (Akopian et al., 1999; Djouhri et al., 2003). The restricted expression profile in a subpopulation of DRG neurons has made the gene encoding $\mathrm{Na}_{\mathrm{v}} 1.8, \mathrm{Scn} 10 a$, an attractive target for nociceptor specific gene deletion. Knock-in mouse lines developed using the Cre-loxP system, where Cre recombinase expression is under the control of the endogenous Scn10a promoter (Agarwal et al., 2004; Nassar et al., 2004), are available and have been a valuable tool to knock-out genes exclusively in nociceptive neurons (Nassar et al., 2004, 2005; Abrahamsen et al., 2008) and to study $\mathrm{Na}_{\mathrm{v}} 1.8$-expressing cells within a heterogeneous DRG population (Gautron et al., 2011; Shields et al., 2012a). Of note, both $\mathrm{Na}_{\mathrm{v}} 1.8$-Cre mouse lines exhibit slight differences in expression profiles, specifically in the spinal cord, brain, and outside the nervous system.

As useful as $\mathrm{Na}_{\mathrm{v}} 1.8$ knock-in mouse lines have become, the mechanism underlying the tight transcriptional regulation of Scn10a remains unclear. To help resolve the regulatory elements responsible for controlling Scn10a gene expression, we cloned the promoter and assessed tissue-specific promoter activity in vitro (Puhl and Ikeda, 2008). In the study, we identified a $3.7 \mathrm{~kb}$ segment of the Scn10a promoter that recapitulated the restricted expression pattern of $\mathrm{Na}_{\mathrm{v}} 1.8$ in a subpopulation of DRG but not 
sympathetic neurons. To validate and extend these studies to an in vivo model, we generated a transgenic mouse line with EGFP under the transcriptional regulation of this putative $S c n 10$ a promoter region.

In Scn10a-EGFP transgenic mice, we found EGFP expression restricted to a subpopulation of primary afferent cell bodies and terminals. Specifically, the EGFP-positive DRG population corresponded with the small- to medium-sized neuronal population, but a small proportion of A-fiber DRG neurons were also EGFP-positive. However, transgene expression was limited to neural crest-derived sensory neurons because EGFP expression was not found in the nodose ganglion or other ganglia of placodal origin. We also found EGFP and functional $\mathrm{Na}_{\mathrm{v}} 1.8$ expression in the CNS, which may be indicative of a novel role of $\mathrm{Na}_{\mathrm{v}} 1.8$ in CNS function and excitability. Thus, the Scn10a-EGFP mouse line generated and characterized in this study is a useful tool to identify $\mathrm{Na}_{\mathrm{v}} 1.8$-expressing neural crest-derived neurons and study the regulatory elements responsible for the restrictive expression of $\mathrm{Na}_{\mathrm{v}} 1.8$.

\section{Materials and Methods Transgenic mouse generation}

All animal studies were conducted in accordance to the National Institutes of Health's Guidelines for Animal Care and Use.

Transgenic mice were generated by pronuclear injection of a linearized DNA construct consisting of the putative promoter region of Scn10a, a $3.7 \mathrm{~kb}$ sequence immediately upstream of the transcriptional start site of the $S c n 10 a$ gene, and the EGFP sequence (see Fig. $1 A$ ). Injected oocytes were transplanted to the oviducts of pseudopregnant foster mice. Three stable male founders were generated (transgenic lines A-C) and backcrossed with C57BL/6N wild-type female mice. All experiments were performed on the sixth to 12th generation, male and female hemizygous offspring of transgenic mouse line A. This transgenic reporter mouse line will be available for distribution from The Jackson Laboratory as stock $\# 025400$.

\section{Acute tissue isolation and dissociation, nuclear microinjections}

Male or female adult mice ( $>30 \mathrm{~d}$ old) were anesthetized by $\mathrm{CO}_{2}$ inhalation and killed by decapitation before dissection. Various ganglia were isolated and placed in chilled Hanks balanced salt solution for further examination. For experiments requiring dissociated neurons, ganglia were transferred to a dissociation medium consisting of $1.3 \mathrm{mg} / \mathrm{ml} \mathrm{col-}$ lagenase (CLS4; Worthington Biochemical), $0.2 \mathrm{mg} / \mathrm{ml}$ trypsin (Worthington Biochemical), and $0.1 \mathrm{mg} / \mathrm{ml}$ DNase I in Earles' balanced salt solution supplemented with $3.6 \mathrm{~g} / \mathrm{L}$ D-glucose and 10 mM HEPES. Ganglia were incubated at $36^{\circ} \mathrm{C}$ for $1 \mathrm{~h}$ in a water bath shaker rotating at 110 rpm. After incubation, neurons were mechanically dissociated by vigorously shaking the flask for $10 \mathrm{~s}$. Neurons were centrifuged $(50 \times \mathrm{g}$ for 6 min) and resuspended in minimum essential medium supplemented with $10 \%$ FBS and $1 \%$ antibiotics $\left(\mathrm{MEM}^{+/+}\right)$twice before plating on polyethylenimine-coated tissue culture dishes. Cells were maintained in a humidified $95 \%$ air $/ 5 \% \mathrm{CO}_{2}$ incubator at $37^{\circ} \mathrm{C}$.

Brains or spinal cord tissue were isolated and placed in chilled, oxygenated aCSF before slicing $300 \mu \mathrm{m}$ sections with a vibrating microtome (Leica). Slices were allowed to recover in oxygenated aCSF incubated at $32^{\circ} \mathrm{C}$ for $1 \mathrm{~h}$. For hypothalamic neuron dissociation, younger mice (P19P23) and isoflurane were used. Coronal sections, $300 \mu \mathrm{m}$, were prepared as described above before incubating slices in oxygenated aCSF containing $0.4 \mathrm{mg} / \mathrm{ml}$ Pronase (Calbiochem) at $36^{\circ} \mathrm{C}$ for $1 \mathrm{~h}$. The hypothalamus was trimmed with a surgical blade and placed in aCSF supplemented with soybean trypsin inhibitor and BSA (both $1 \mathrm{mg} / \mathrm{ml}$ ). Tissue was mechanically dissociated with a series of fire-polished Pasteur pipettes of decreasing diameter before plating on polyethylenimine-coated tissue culture dishes. Cells were allowed to settle for $30 \mathrm{~min}$ at room temperature before electrophysiological recording.
Plasmid cDNA (100 ng/ $/$ l) similar to the construct used to generate the transgenic mice (i.e., a $3.7 \mathrm{~kb}$ promoter region of $\mathrm{Scn} 10 \mathrm{a}$ upstream of the EGFP gene) was injected into the nuclei of DRG or nodose neurons from adult (6- to 12-week-old) male Wistar rats, as previously described (Ikeda, 2004; Lu et al., 2009). Briefly, 4-6 h following cell dissociation, cDNA was injected with a FemtoJet microinjector and 5171 micromanipulator (Eppendorf) using an injection pressure and duration of 140 $160 \mathrm{hPa}$ and $0.3 \mathrm{~s}$, respectively. To identify successfully injected cells, a mixture of nuclear-targeted dsRed 2 constructs (dsRed2nuc, $5 \mathrm{ng} / \mu \mathrm{l}$ each; Clontech) under the control of one of following promoters: cytomegalovirus, ubiquitin, or elongation factor- $1 \alpha$, was coinjected with the reporter construct. Following injections, neurons were maintained in a humidified $95 \%$ air $/ 5 \% \mathrm{CO}_{2}$ incubator at $37^{\circ} \mathrm{C}$ for $2 \mathrm{~d}$ in $\mathrm{MEM}^{+/+}$ supplemented with $5 \mathrm{ng} / \mathrm{ml}$ nerve growth factor (NGF) and $5 \mathrm{ng} / \mathrm{ml}$ glial cell line-derived neurotrophic factor (GDNF; Calbiochem).

\section{Molecular biology}

Primers and PCR amplification. The following primer sets were used for PCR experiments. For genotyping: forward, 5' -CTTCGTGGAGGAGCCCCGGAC-3', reverse, 5' -GCTGAAGCACTGCACGCCGTAGG-3'; Scn10a: forward, 5'-GGACCTGGCTCCATACCTGG-3', reverse, 5' GAGGTTCACACCCATGATGCTG-3'; $\beta$-actin: forward, $5^{\prime}$-GCCATCCTGCGTCTGGACCTG-3' ${ }^{\prime}$, reverse, $5^{\prime}$-GTACTTGCGCTCAGGA GGAGC-3'.

Unless otherwise stated, PCR amplification was performed with $2 \times$ GoTaq Hot Start Polymerase Green Master Mix (Promega) for 35 cycles $\left(94^{\circ} \mathrm{C}\right.$ for $30 \mathrm{~s}, 60^{\circ} \mathrm{C}$ for $30 \mathrm{~s}$, and $72^{\circ} \mathrm{C}$ for $1 \mathrm{~min}$ ) and final extension at $72^{\circ} \mathrm{C}$ for $5 \mathrm{~min}$. PCR products were analyzed by agarose gel electrophoresis and visualized using SYBR safe DNA gel stain (Invitrogen).

Genotyping. Ear punches were collected from anesthetized animals and processed with the DNeasy Blood and Tissue kit (QIAGEN) following the manufacturer's instructions. The primer set used for genotyping was designed to amplify the $3^{\prime}$-end of the inserted Scn10a promoter region and initial portion of the EGFP gene.

Single-cell PCR. Single DRG neurons, of small to medium diameter, were collected by suction into a fire-polished glass capillary. The pipette tip containing a single cell was broken inside a PCR tube containing components from the OneStep RT-PCR kit (QIAGEN). First-strand cDNA synthesis was performed at $50^{\circ} \mathrm{C}$ for $30 \mathrm{~min}$. The samples were then heated at $95^{\circ} \mathrm{C}$ for $15 \mathrm{~min}$ to inactivate reverse transcriptase and activate HotStarTaq DNA polymerase. PCR was performed for 40 cycles consisting of $94^{\circ} \mathrm{C}$ for $30 \mathrm{~s}, 60^{\circ} \mathrm{C}$ for $30 \mathrm{~s}$, and $72^{\circ} \mathrm{C}$ for $1 \mathrm{~min} 30 \mathrm{~s}$. The final extension was performed at $72^{\circ} \mathrm{C}$ for $5 \mathrm{~min}$. Scn10a transcript and $\beta$-actin mRNA, as an internal reference, were amplified concurrently (i.e., multiplexed) with the primer sets detailed above.

cDNA synthesis and conventional PCR. Tissue punches of various brain regions and whole ganglia were collected and placed immediately in cold Trizol (Ambion). Samples were homogenized, total RNA was extracted using the RNeasy micro kit (QIAGEN), and first strand cDNA was synthesized with QuantiTect Reverse Transcription kit (QIAGEN) from 200 ng total RNA. PCR amplification of $S c n 10 a(0.8 \mu \mathrm{m}$ primers $)$ and $\beta$-actin $(0.2 \mu \mathrm{M}$ primers $)$ was performed concurrently. Primers were designed to span intron sequences, thus eliminating interference from potential genomic DNA contamination. In addition, a control reaction from DRG mRNA performed in the absence of reverse transcriptase was included.

$q P C R$. Quantitative real-time PCR was performed with a StepOnePlus Real-Time System, TaqMan Universal Master Mix II, and TaqMan Gene Expression Assays (all from Applied Biosystems). Predesigned primerprobe sets for mouse Scn10a (Mm00501467_m1) or $\beta$-actin (mouse ACTB, catalog \#4352341E) and $1 \mu$ template cDNA from various brain regions or whole ganglia were used in $20 \mu \mathrm{l}$ of reaction mixture. The mixture was initially heated to $50^{\circ} \mathrm{C}$ for $5 \mathrm{~min}$, and $95^{\circ} \mathrm{C}$ for $10 \mathrm{~min}$, then cycled 45 times through a melting step at $95^{\circ} \mathrm{C}$ for $15 \mathrm{~s}$ and annealing/ extension step at $60^{\circ} \mathrm{C}$ for $1 \mathrm{~min}$. At least three biological replicates for each tissue group were examined. To analyze the relative gene expression, the comparative $2^{-\Delta \Delta \mathrm{Ct}}$ method was used (Schmittgen and Livak, 2008). Briefly, the $\mathrm{C}_{\mathrm{T}}$ values, defined as the cycle number at which the fluorescence intensity of the reporter dye crosses a threshold determined by StepOne software, were obtained for $S c n 10 a$ and $\beta$-actin genes. The $\Delta \mathrm{C}_{\mathrm{T}}$ 
value for each sample was calculated using the equation: $\Delta C_{T}=C_{T}$ $(S c n 10 a)-C_{\mathrm{T}}$ ( $\beta$-actin). The fold difference in gene expression between tissue groups was obtained from the formula $2^{-\Delta \Delta \mathrm{Ct}}=\left[\Delta \mathrm{C}_{\mathrm{T}}\right.$ (tissue group) - mean $\Delta \mathrm{C}_{\mathrm{T}}$ for DRGs].

\section{Immunostaining and imaging}

Immunohistochemistry (IHC). Isolated tissues or hemisected brains were drop-fixed in $4 \%$ PFA overnight at $4^{\circ} \mathrm{C}$ and then transferred to a $30 \%$ sucrose solution at $4^{\circ} \mathrm{C}$ until tissues sank to the bottom of the vessel. Tissues were immersed in Optimum Cutting Temperature Medium (Tissue-Tek) and frozen at $-80^{\circ} \mathrm{C}$. Thin $(16-25 \mu \mathrm{m})$ sections of tissue, obtained using a cryostat (Leica), were mounted on SuperFrost Plus microscope slides (Electron Microscopy Sciences) and stored at $-20^{\circ} \mathrm{C}$ before processing. Unless otherwise stated, the remaining IHC steps were performed at room temperature. Cryosections were rehydrated in PBS for $20 \mathrm{~min}$, permeabilized with $0.3 \%$ Triton X-100 for $25 \mathrm{~min}$, and immersed in $0.2 \%$ Sudan Black B for $1.5 \mathrm{~h}$ to reduce lipofuscin-like autofluorescence. Slides were destained with PBS for $1 \mathrm{~h}$ before blocking with a solution of $4 \%$ nonfat milk, $2 \%$ BSA, and $2 \%$ normal goat serum in Tris-buffered saline with $0.05 \%$ Tween 20 (TBS-T, $10 \mathrm{~mm}$ Tris base, 250 $\mathrm{mm} \mathrm{NaCl}, \mathrm{pH} 7.5$ ) for $1 \mathrm{~h}$. An extra blocking step with unconjugated goat anti-mouse Fab fragments ( $10 \mu \mathrm{g} / \mathrm{ml}$, Jackson ImmunoResearch Laboratories) in blocking solution was performed for $1 \mathrm{~h}$ before primary antibody, chicken anti-EGFP (1:2000, Aves Labs, catalog \#GFP-1010), and mouse anti- $\mathrm{Na}_{\mathrm{v}} 1.8$ (1:10 tissue culture supernatant, NeuroMab, clone N134/12) was applied overnight at $4^{\circ} \mathrm{C}$. According to the product datasheet, the $\mathrm{Na}_{\mathrm{v}} 1.8$ antibody used in these experiments was developed against the $\mathrm{C}$ terminus of rat $\mathrm{Na}_{\mathrm{v}} 1.8$ (amino acids 1724-1956), which has $93 \%$ identity with mouse $\mathrm{Na}_{\mathrm{v}} 1.8$, has reactivity in mouse tissue, and has been validated in a $\mathrm{Na}_{\mathrm{v}} 1.8$ knock-out mouse. Secondary antibodies, goat anti-chicken conjugated to AlexaFluor- 488 and goat anti-mouse conjugated to AlexaFluor-555 (both 1:2000, Invitrogen) were applied for $2 \mathrm{~h}$. After sufficient washing with TBS-T and PBS, coverslips were mounted on slides with Fluoromount-G (Electron Microscopy Sciences).

Hematoxylin and eosin staining of skin sections. Skin from the mouse footpad was removed, fixed with $4 \%$ PFA for $30 \mathrm{~s}$, and flash frozen in liquid nitrogen. Thin cryosections were mounted on SuperFrost Plus microscope slides, completely dried, then rehydrated with PBS, and a coverslip was mounted with Fluoromount-G (Electron Microscopy Sciences). Fluorescence images were acquired before counterstaining with the NovaUltra H and E stain kit (IHC World), as per the manufacturer's instructions.

Live-cell staining. Two hours after plating, dissociated neurons on tissue culture dishes were removed from the incubator and gently washed with Dulbecco's PBS with $\mathrm{Ca}^{2+}$ and $\mathrm{Mg}^{2+}\left(\mathrm{DPBS}^{+/+}\right)$, then exchanged with a blocking solution of $2 \%$ BSA in DPBS ${ }^{+/+}$with $0.03 \%$ Triton $\mathrm{X}-100$. Isolectin B4 (IB4) conjugated to AlexaFluor-568 (5 $\mu \mathrm{g} / \mathrm{ml}$, Invitrogen) or cholera toxin B subunit (CtB) conjugated to rhodamine (5 $\mu \mathrm{g} / \mathrm{ml}$, List Biological) was added and dishes were incubated at $37^{\circ} \mathrm{C}$ for $30 \mathrm{~min}$. Neurons were washed $3 \times$ with blocking solution then $3 \times$ with DPBS $^{+/+}$. Dishes were kept in the dark until image acquisition.

Immunocytochemistry (ICC). Dissociated neurons plated on tissue culture dishes were gently washed with PBS before fixing with 2\% PFA for 30 min at room temperature. After washing out fixative with PBS, neurons were permeabilized with $0.3 \%$ Triton X-100 in PBS for 20 min at room temperature. Following solution exchange with PBS, a blocking solution of $4 \%$ nonfat milk, $2 \%$ BSA, and $2 \%$ normal goat serum in TBS-T was added for $1 \mathrm{~h}$ at room temperature. For dishes treated with mouse monoclonal primary antibodies, an additional incubation with unconjugated goat anti-mouse Fab fragments $(10 \mu \mathrm{g} / \mathrm{ml})$ in blocking solution was applied for $1 \mathrm{~h}$ at room temperature after the blocking step. Primary antibodies in blocking solution were incubated with cells overnight at $4^{\circ} \mathrm{C}$. One of the following primary antibodies was applied: mouse anti$\mathrm{Na}_{\mathrm{v}} 1.7$ (1:400, NeuroMab, clone 68/6), mouse anti-Na 1.8 (1:200 purified antibody or 1:10 tissue culture supernatant, NeuroMab, clone 134/ 12), mouse anti-EGFP (1:400, Millipore Bioscience Research Reagents, catalog \#MAB3580), rabbit anti-Neurofilament 200 (1:2000, Abcam, catalog \#ab8135), mouse anti-calcitonin gene-related peptide (CGRP; 1:300, Abcam, catalog \#ab81887), rabbit anti-Substance P (1:1000, Im-
munoStar, catalog \#20064), and rabbit anti-TH (1:1000, Pel-Freez, P40101). After washing cells with TBS-T for $1 \mathrm{~h}$, cells were treated with fluorescently tagged secondary antibodies (goat anti-mouse or goat antirabbit conjugated to AlexaFluor-555, 1:2000, Invitrogen) for $2 \mathrm{~h}$ at room temperature. Cells were washed with TBS-T for $1 \mathrm{~h}$ and then exchanged for PBS before imaging. All staining experiments included parallel negative controls, which received the same treatment except without primary antibody incubation.

Fluorescence imaging. Thick tissues $(>100 \mu \mathrm{m})$ were imaged with a Zeiss LSM510 Meta confocal microscope using ZEN 2008 acquisition software (Carl Zeiss). $z$-stack images were acquired with a $488 \mathrm{~nm}$ excitation wavelength and a 500-550 $\mathrm{nm}$ bandpass emission filter using a $10 \times$ objective $(0.30 \mathrm{NA})$, and then compiled to a single $Z$-projection image. For lower-magnification fluorescence images, an Olympus MVX10 microscope was used. To image IHC and ICC experiments, phase-contrast and fluorescence images were acquired using a Zeiss Observer Z1 microscope (Carl Zeiss) equipped for fluorescence imaging and an Andor CCD camera (Clara) controlled by open-source Micromanager software (version 1.4.18) (Edelstein et al., 2010) or a Zeiss Axiovert 200 microscope (Carl Zeiss) equipped for fluorescence imaging and a Hamamatsu CCD camera (ORCA-ER) controlled by Volocity acquisition software. Either a $20 \times(0.40 \mathrm{NA})$ or $63 \times(1.2 \mathrm{NA})$ objective was used. Filters appropriate for EGFP (472/30 nm excitation, 520/35 nm emission), and red fluorescence (534/22 nm excitation, 593/40 nm emission) were used and exposure times for green $(2 \mathrm{~s})$ and red $(0.5 \mathrm{~s})$ fluorescence images were kept consistent across all samples.

\section{Electrophysiology}

$\mathrm{Na}^{+}$-channel currents $\left(I_{N a}\right)$ were recorded using conventional wholecell patch-clamp techniques (Hamill et al., 1981). Patch electrodes were pulled from borosilicate glass capillaries ( $1.65 \mathrm{~mm}$ outer diameter, 1.20 mm inner diameter, King Precision Glass) using a Model P-97 micropipette puller (Sutter Instrument). The patch electrodes were coated with silicone elastomer (Sylgard 184, Dow Corning) and fire-polished. A Ag/ $\mathrm{AgCl}$ pellet connected to the bath solution via a $0.15 \mathrm{M} \mathrm{NaCl} /$ agar bridge was used as a ground. The cell membrane capacitance was cancelled, and series resistance was compensated ( $>85 \%$ prediction and correction; lag set to $5 \mu \mathrm{s}$ ) with a patch-clamp amplifier (Axopatch 200B, Molecular Devices). Voltage protocol generation and data acquisition were performed using custom-designed software (S5) on a Macintosh G4 computer (Apple). Current traces were filtered at $5 \mathrm{kHz}(-3 \mathrm{~dB}$; 4-pole Bessel), digitized at $10 \mathrm{kHz}$ with a 16-bit analog-to-digital converter board (ITC-18, HEKA), and stored on the computer for later analyses.

For recording $I_{\mathrm{Na}}$ from DRG neurons, patch pipettes were filled with an internal solution containing the following (in $\mathrm{mm}$ ): $30 \mathrm{NaCl}, 80 \mathrm{Cs}$ methanesulfonate, 10 HEPES, 10 sucrose, 11 EGTA, $1 \mathrm{CaCl}_{2}$, 6 Triscreatine phosphate, $4 \mathrm{Mg}$-ATP, $0.1 \mathrm{Na}_{2}$-GTP, pH 7.2, with TEA-OH. External $I_{\mathrm{Na}}$ recording solution consisted of the following (in $\mathrm{mM}$ ): 60 $\mathrm{NaCl}, 60$ TEA-Cl, 10 HEPES, 15 D-glucose, $10 \mathrm{MgCl}_{2}$, osmolality adjusted to 310-320 mOsm with sucrose, $\mathrm{pH}$ 7.4, with TEA-OH. For recording $I_{\mathrm{Na}}$ from central neurons, $\mathrm{NaCl}$ was reduced in the internal solution to 10 and $100 \mathrm{~mm}$ CsF replaced Cs methanesulfonate. Also, the concentration of $\mathrm{NaCl}$ was increased to $140 \mathrm{~mm}$ in the external $I_{\mathrm{Na}}$ recording solution. All recordings were performed at room temperature $\left(20^{\circ} \mathrm{C}-24^{\circ} \mathrm{C}\right)$.

Drugs for electrophysiological experiments were diluted to final concentrations from stock solutions on the day of experiment and applied directly onto neurons using a custom-made gravity-fed perfusion system with separate perfusion lines feeding into a 4-bore glass capillary tube (VitroCom) connected to a fused silica capillary tube. A constant flow of external solution was applied onto cells during baseline recordings and switched to a drug solution during drug applications to avoid flowinduced artifacts. Tetrodotoxin-resistant (TTX-R) $I_{\mathrm{Na}}$ was measured following application of $3 \mu \mathrm{M}$ TTX and TTX-sensitive (TTX-S) $I_{N a}$ was obtained by subtracting TTX-R $I_{\mathrm{Na}}$ traces from total $I_{\mathrm{Na}}\left(I_{\mathrm{Na}}\right.$ traces recorded before TTX application).

$I_{N a}$-voltage relationships were studied by applying a series of $70 \mathrm{~ms}$ depolarizing voltage steps from a holding potential of $-80 \mathrm{mV}$, every 10 s. To generate activation curves, peak inward currents from the $I-V$ 
recording protocol were converted to conductance values using the equation, $G=I /\left(V_{\mathrm{m}}-\right.$ $E_{N a}$ ), where $G$ is conductance, $I$ is the peak current, $V_{\mathrm{m}}$ is the membrane potential step used to elicit the response, and $E_{N a}$ is the reversal potential for sodium (determined from the $x$-axis intercept of a linear fit to the ascending limb of the $I-V$ curve). Conductance was normalized to the maximum conductance value and fit (Marquardt-Levenberg algorithm, Igor PRO version 6.3, WaveMetrics) to the Boltzmann equation $G / G_{\max }=1 /\left(1+\exp \left[\left(V_{\mathrm{m}}-\right.\right.\right.$ $\left.\left.\left.V_{1 / 2, a c t}\right) / k_{a}\right]\right)$, where $G / G_{\max }$ is the fractional peak membrane conductance, $V_{\mathrm{m}}$ is the membrane potential, $V_{1 / 2, a c t}$ is the half-activation voltage, and $k_{a}$ is a slope factor. To generate steady-state inactivation curves, cells were stepped with a series of $500 \mathrm{~ms}$ conditioning pulses $(-100$ to $50 \mathrm{mV})$ followed by a $100 \mathrm{~ms}$ test pulse to $10 \mathrm{mV}$. Peak inward currents from the test pulse were normalized to the maximum current amplitude and fit to the Boltzmann equation $I / I_{\max }=1 /\left(1+\exp \left[\left(V_{c}-V_{1 / 2, \text { inact }}\right) / k_{i}\right]\right)$, where $I$ is the peak $I_{N a}$ evoked during the test pulse, $I_{\max }$ is the maximal current, $V_{c}$ is the voltage of the conditioning pulse before the test pulse, $V_{1 / 2 \text {, inact }}$ is the half-inactivation voltage, and $k_{i}$ is a slope factor.

\section{Drugs and chemicals, analysis and statistical testing}

Unless otherwise stated, all chemicals were purchased from Sigma-Aldrich. A-803467 was purchased from Alomone Labs, and TTX was purchased from Abcam.

ImageJ software (version 1.48) was used to analyze and adjust contrast of images for presentation in figures. IGOR Pro software (version 6.3, WaveMetrics) was used to analyze current traces and ICC experiments. For analyzing colabeling experiments, a customwritten program in IGOR Pro was used to automatically select regions of interest around neurons in phase-contrast images, and fluorescence intensity was measured from subsequent images from the green and red fluorescence channels.

Statistical tests were performed with GraphPad Prism 6 for Mac OS X (GraphPad Software). Data are expressed as mean \pm SEM, except for Figure 6Eii where the proportions of cells with 95\% confidence intervals are shown. Statistical significance between two groups was determined using an unpaired Student's $t$ test or the Fisher's exact test for Figure 6Eii, and an ANOVA with Holm-Sidak's multiplecomparisons test was used to statistically compare three or more groups. $p<0.05$ was considered statistically significant.

\section{Results}

\section{Generation of transgenic mouse lines}

Three transgenic mouse lines were generated following pronuclear injection of the putative Scn10a promoter construct (Fig. 1A). Offspring from founder mice $\mathrm{B}$ failed to breed and this line could not be maintained. Transgenic mouse line $\mathrm{C}$ continued to breed but EGFP expression in peripheral sensory ganglia steadily

B

D
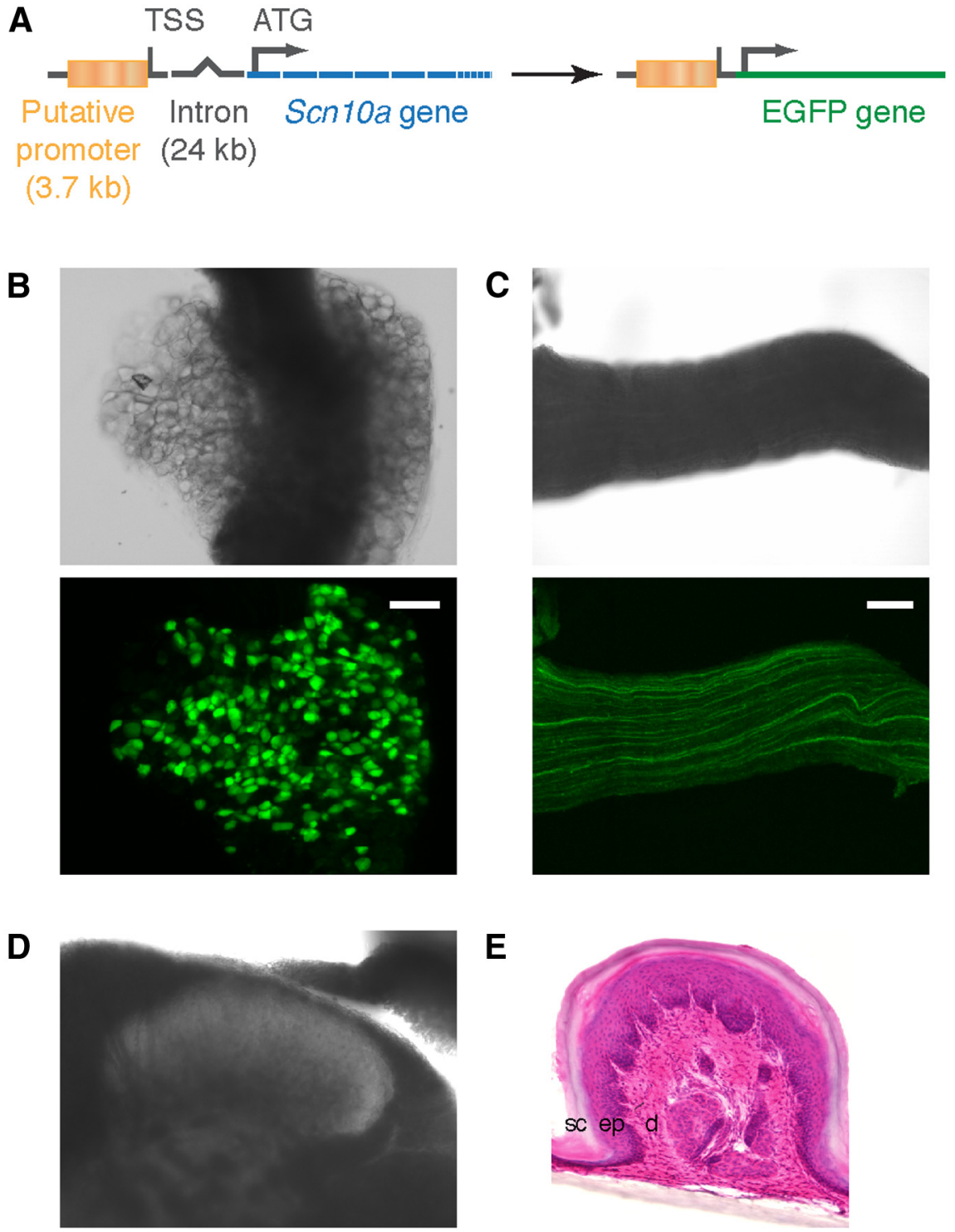

E
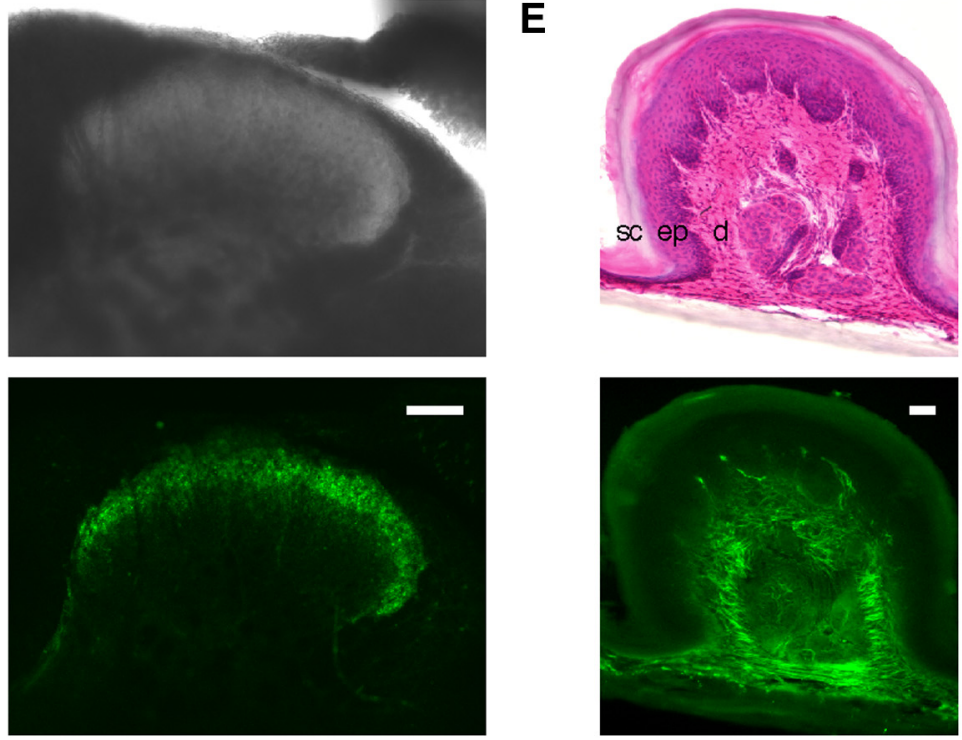

Figure 1. EGFP expression in peripheral sensory neurons and primary sensory afferent fibers of Scn 10a-EGFP mice. A, Schematic of linearized construct used to generate transgenic mouse line. A $3.7 \mathrm{~kb}$ sequence upstream of a $24 \mathrm{~kb}$ intron and transcriptional start site (TSS) of the Scn10a gene was used as the promoter to drive EGFP expression in transgenic mice. $\boldsymbol{B}-\boldsymbol{D}$, Top, Phase-contrast images. Bottom, EGFP fluorescence images. $\boldsymbol{B}$, Thoracic DRG. C, Dorsal root branch. $\boldsymbol{D}$, Dorsal side of a transverse spinal cord slice $(300 \mu \mathrm{m})$. Note the EGFP fibers terminating in Lamina Il of the spinal cord. $\boldsymbol{E}$, Cross-section of mouse footpad (glabrous) skin. Top, Hematoxylin and eosin stain of glabrous skin section clearly labeling the stratum corneum (sc), epidermis (ep), and dermis (d) layers. Bottom, Fluorescence image of skin section taken before hematoxylin and eosin staining. Note the EGFP fibers extending into dermal papillae and terminating in the dermis layer, not crossing into the stratum spinosum layer of the epidermis. Scale bars, $100 \mu \mathrm{m}$.

declined in subsequent generations. By the fourth generation, the percentage of DRG neurons expressing EGFP dropped to $<10 \%$; therefore, transgenic line $\mathrm{C}$ was not studied further. EGFP expression in the DRG of transgenic mouse line A was relatively 
Table 1. Characterization of the EGFP-positive peripheral sensory neuron population $^{a}$

\begin{tabular}{|c|c|c|c|}
\hline Label & \% positive for label & $\begin{array}{l}\% \text { double-labeled cells } \\
\text { (as \% EGFP-positive } \\
\text { cells) }\end{array}$ & $\begin{array}{l}\text { \% double-labeled cells } \\
\text { (as \% label-positive } \\
\text { cells) }\end{array}$ \\
\hline \multicolumn{4}{|l|}{ For DRG neurons } \\
\hline $\begin{array}{l}\text { EGFP, transgene } \\
\text { expression }\end{array}$ & $45.7 \pm 2.2(40)$ & & \\
\hline EGFP-IR & $35.5 \pm 3.6(4)$ & $97.9 \pm 1.2$ & $90.7 \pm 2.8$ \\
\hline $\mathrm{Na}_{\mathrm{v}} 1.8$ & $44.6 \pm 2.2(12)$ & $69.7 \pm 1.6$ & $80.2 \pm 4.6$ \\
\hline IB4 & $35.4 \pm 1.5(18)$ & $56.7 \pm 1.7$ & $75.2 \pm 4.2$ \\
\hline CGRP & $14.6 \pm 1.1(5)$ & $18.7 \pm 0.9$ & $61.4 \pm 4.0$ \\
\hline Substance P & $8.0 \pm 0.8(4)$ & $7.2 \pm 0.9$ & $45.9 \pm 4.7$ \\
\hline $\mathrm{CtB}$ & $36.5 \pm 1.3(12)$ & $9.6 \pm 1.0$ & $11.4 \pm 1.7$ \\
\hline NF200 & $25.9 \pm 1.1(3)$ & $8.6 \pm 1.4$ & $10.8 \pm 3.3$ \\
\hline TH & $9.0 \pm 0.7(5)$ & $5.6 \pm 0.3$ & $32.2 \pm 3.9$ \\
\hline $\mathrm{Na}_{v} 1.7$ & $91.3 \pm 3.0(9)$ & $95.8 \pm 1.7$ & $41.9 \pm 5.0$ \\
\hline \multicolumn{4}{|l|}{ For ND neurons } \\
\hline $\begin{array}{l}\text { EGFP, transgene } \\
\text { expression }\end{array}$ & $7.0 \pm 1.2(13)$ & & \\
\hline $\mathrm{Na}_{\mathrm{v}} 1.8$ & $46.1 \pm 9.0(5)$ & $82.9 \pm 10.2$ & $14.6 \pm 3.8$ \\
\hline \multicolumn{4}{|c|}{$\begin{array}{l}\text { aSummary of live-cell staining and ICC experiments on dissociated DRG or ND neurons isolated from Scn 10a-EGFP } \\
\text { mice. Fluorescence from individual neurons measured using a custom program written with Igor software (detailed } \\
\text { in Materials and Methods). Staining with secondary antibody alone (i.e. no primary antibody) was used to determine } \\
\text { the boundary between positive and negative red fluorescence intensity, and the boundary between positive and } \\
\text { negative green fluorescence was set at } 750 \text { (for the two discrete populations of EGFP fluorescence intensity, see Fig. } \\
\text { 3B). Double-labeled (EGFP-positive and label-positive) neurons expressed as either a percentage of total EGFP- } \\
\text { positive (middle column) or label-positive (right column) neurons. n values for each group are biological replicates } \\
\text { (different animals) and indicated in parentheses. }\end{array}$} \\
\hline
\end{tabular}

high in a large number of cells (Fig. $1 B$ ) and consistent up to the 12 th generation offspring. Insertion of the transgene randomly into the genome appeared to be well tolerated in transgenic mouse line A as no overt abnormalities in development or breeding were observed. All further experiments in this study used transgenic line A.

\section{EGFP expression in DRG neurons and primary sensory afferents terminals}

As mentioned previously, EGFP was observed within cell bodies of the DRG (Fig. 1B) and fibers in the dorsal root branch (Fig. $1 C)$. Neurons expressing EGFP were distributed throughout the ganglion, and EGFP expression was similar in all DRG along the spinal column (data not shown). In enzymatically dissociated DRG neurons of Scn10a-EGFP mice, the percentage of neurons expressing EGFP ranged between $20 \%$ and $71 \%$ and averaged $46 \%$ (Table $1 ; n=40$ ). Sporadically, a mouse genotyped as positive for the transgene would have little to no EGFP in DRG neurons (5 of 95 positive mice with $<2 \%$ total DRG neurons expressing EGFP). No age- or sex-related association between affected animals could be determined. Tissue samples from these animals were excluded from analysis, and only Scn10a-EGFPpositive mice with $>20 \%$ of DRG neurons expressing EGFP were characterized further.

Primary sensory afferents project to the dorsal horn of the spinal cord, and EGFP was observed in acutely prepared spinal cord slices from Scn10a-EGFP-positive mice (Fig. 1D). The EGFP signal concentrated in the substantia gelatinosa or Lamina II of the dorsal horn where C-fibers predominantly terminate. Primary sensory afferents also project to peripheral tissues, including the skin, and EGFP expression was probed in skin samples from the footpads of Scn10a-EGFP-positive mice (Fig. 1E). Bright EGFP-positive fibers were detected in the dermis layer of footpad skin extending into dermal papillae but do not cross into the stratum spinosum layer of the epidermis. Hence, primary
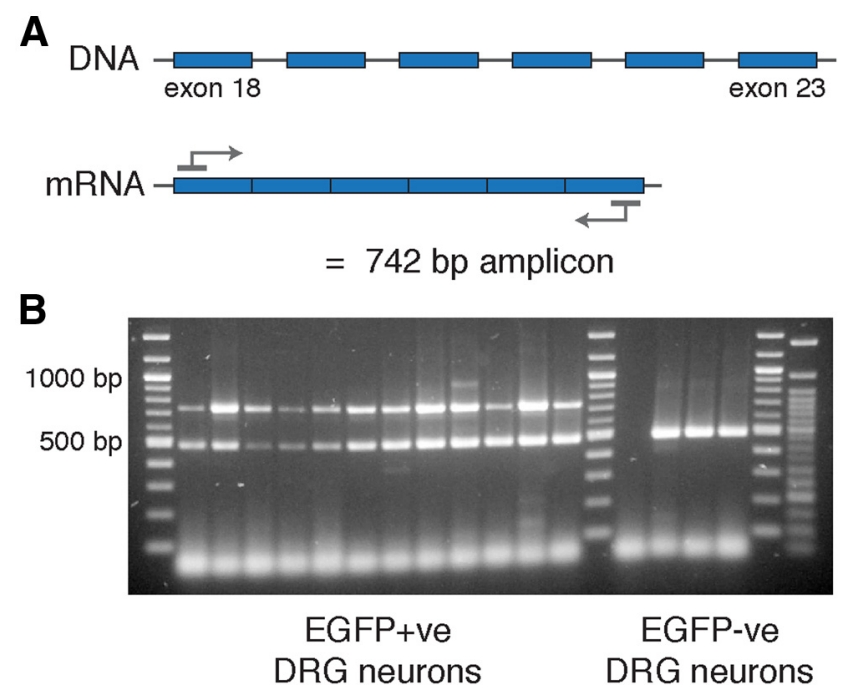

Figure 2. Correlation of EGFP expression with $S c n 10 a$ transcript in DRG neurons from Scn10a-EGFP mice. $\boldsymbol{A}$, Schematic of primer set used to amplify $S \mathrm{Sn} 10$ a transcript by single-cell $P C R$. Primers were designed to span 6 exons (exon $18-23$ ) and generate a 742 bp amplicon. $\boldsymbol{B}$, The resultant $P C R$ products were separated and visualized on a $1.5 \%$ agarose gel. $\beta$-actin amplicon is $500 \mathrm{bp}$ in length.

sensory neuron somata, fibers, and both central and peripheral terminals from Scn10a-EGFP mice express EGFP.

\section{EGFP expression in DRG neurons correlates with Scn10a mRNA and $\mathrm{Na}_{\mathrm{v}} 1.8$ protein}

To validate the $S c n 10 a$-EGFP mouse line as an effective reporter of voltage-gated sodium channels subtype $1.8\left(\mathrm{Na}_{\mathrm{v}} 1.8\right)$, the correlation between EGFP expression and $\mathrm{Scn} 10 \mathrm{a}$ gene products was assessed.

Individual DRG neurons from Scn10a-EGFP mice were selected following enzymatic dissociation and subjected to singlecell PCR. Scn10a and $\beta$-actin transcripts were amplified, and the PCR products obtained are shown in Figure 2B. A 742 bp amplicon, corresponding to the predicted size of Scn10a transcript, was detected in 35 of 37 EGFP-positive DRG neurons. Therefore, EGFP expression in Scn10a-EGFP mice correlates well with the presence of Scn10a mRNA.

An antibody with reactivity to mouse $\mathrm{Na}_{\mathrm{v}} 1.8$ was used to detect the presence of $\mathrm{Na}_{\mathrm{v}} 1.8$ protein. Whole DRG sections and dissociated DRGs from Scn10a-EGFP mice were subject to immunostaining and fluorescence imaging (Fig. $3 A$ ). Most small- to mediumdiameter DRG neurons expressed EGFP (Fig. 3A, middle panels; mean diameter $=26.5 \pm 0.02 \mu \mathrm{m}, n=43,608$ EGFP-positive DRG neurons from 40 animals) and were immunoreactive to $\mathrm{Na}_{\mathrm{v}} 1.8$ $\left(\mathrm{Na}_{\mathrm{v}} 1.8\right.$-IR; Fig. $3 A$, right panels). An $x-y$ plot of the fluorescence intensity in the red and green channels from individual DRG neurons reveals four discrete populations (Fig. $3 B$ ). The majority of cells are within the top right and bottom left quadrants of the scatterplot corresponding to the EGFP-positive/ $\mathrm{Na}_{\mathrm{v}} 1.8-\mathrm{IR}$ and EGFP-negative/non- $\mathrm{Na}_{\mathrm{v}} 1.8$-IR population, respectively; $80 \%$ of all $\mathrm{Na}_{\mathrm{v}} 1.8$-IR cells expressed EGFP, and almost $70 \%$ of all EGFPpositive DRG neurons were immunoreactive to $\mathrm{Na}_{\mathrm{v}} 1.8$ (Table 1). As a control, an antibody against EGFP was used to test ICC and analysis procedures. Almost 98\% of EGFP-positive DRG neurons were immunoreactive to the EGFP antibody (Table 1).

Currents from $\mathrm{Na}_{\mathrm{v}} 1.8$ channels have distinct biophysical properties and can be pharmacologically isolated using TTX. Therefore, using solutions designed to isolate sodium currents 
A
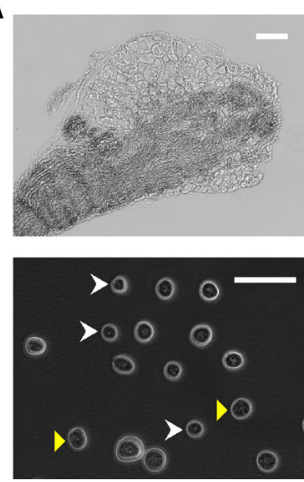
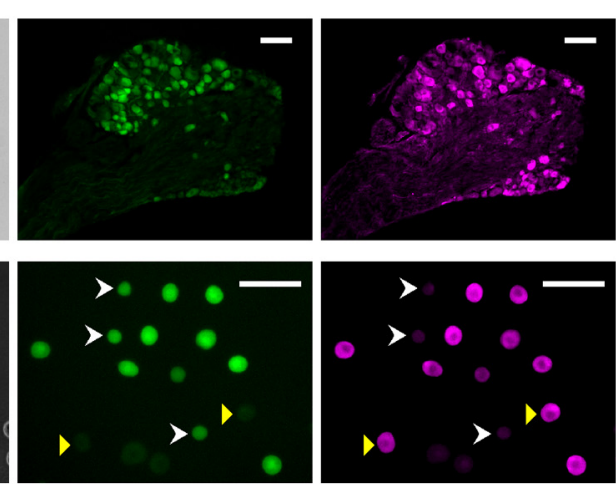

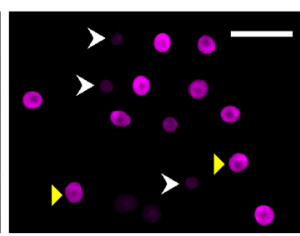

B

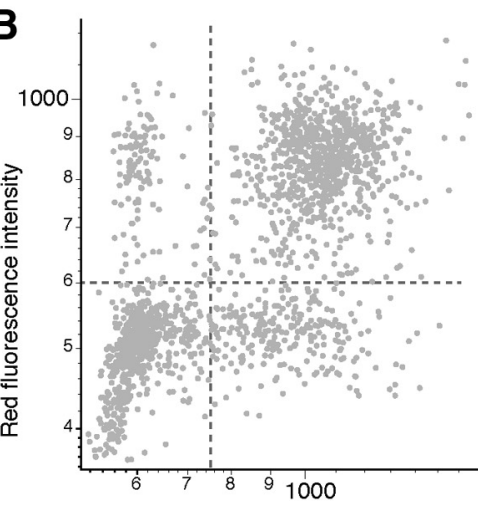

Green fluorescence intensity

Figure 3. Correlation of EGFP expression with $\mathrm{Na}_{\mathrm{v}} 1.8$ protein in DRG neurons from Scn10a-EGFP mice. A, Immunoreactivity (IR) of DRGs from an Scn10a-EGFP mouse to antibodies against $\mathrm{Na}_{\mathrm{v}} 1.8$ protein (NeuroMab). Phase-contrast (left), EGFP (middle), and red fluorescence (right) images of immunostained DRGs. Top, IHC of sectioned DRG tissue. Bottom, ICC of dissociated DRG neurons. White arrowheads indicate EGFP-positive DRG neurons lacking $\mathrm{Na}_{v} 1.8-$ IR. Yellow arrowheads indicate $\mathrm{Na}_{\mathrm{v}} 1.8$-IR DRG neurons lacking EGFP expression. Scale bar, $50 \mu \mathrm{m}$. B, Scatterplot from a representative ICC experiment. Green and red fluorescence intensity represents transgene (EGFP) expression and $\mathrm{Na}_{\mathrm{v}} 1.8-\mathrm{IR}$, respectively, of DRG neurons from Scn10a-EGFP mice. ROls were automatically selected around dissociated DRG neurons in the phase-contrast image, and fluorescence intensity was measured from subsequent images collected from green and red channels. Each dot indicates an individual cell. Dashed lines indicate the boundary between groups determined by staining in negative controls (secondary antibody alone) and visual confirmation.
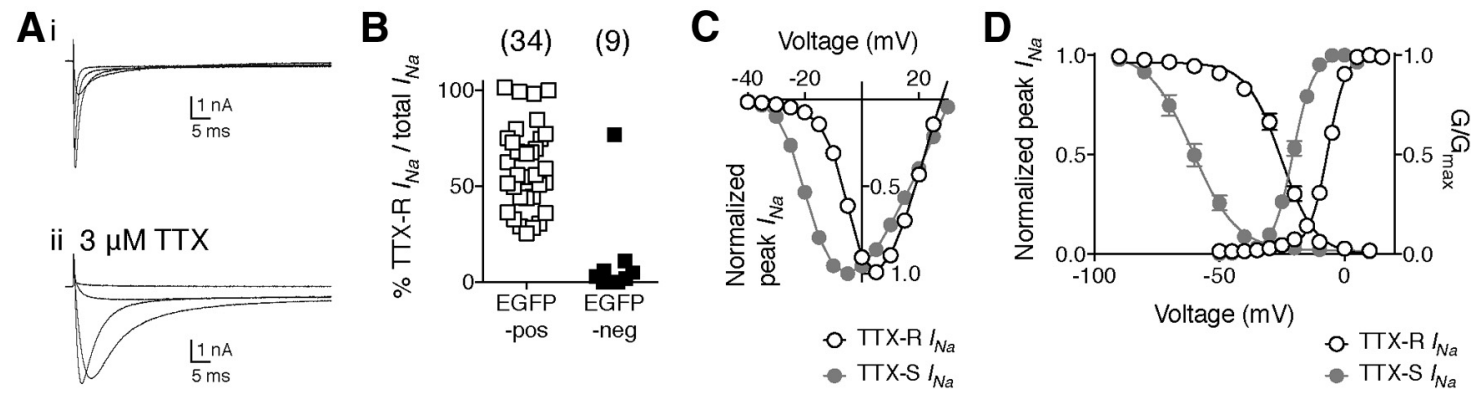

Figure 4. Correlation of EGFP expression with functional $\mathrm{Na}_{\mathrm{v}} 1.8$ channels in DRG neurons from Scn10a-EGFP mice. $A$, Representative electrophysiological recording traces of sodium currents $\left(I_{N a}\right)$ from an EGFP-negative $(i)$ or EGFP-positive DRG neuron in the presence of $3 \mu \mathrm{M}$ TTX (ii). Note the slower activation and inactivation kinetics of TTX-R $I_{N a}$. Calibration: $y$-axis, $1 \mathrm{nA} ; x$-axis, $5 \mathrm{~ms}$ for both. $\boldsymbol{B}$, Proportion of TTX-R $I_{N a}$ expressed as a percentage of total $I_{N a}$ in EGFP-positive $(\square)$ and EGFP-negative $(\square)$ DRG neurons. Peak $I_{N a}$ amplitude recorded at $0 \mathrm{mV}$ before and after application of $3 \mu \mathrm{m}$ TTX was used to calculate percentages. Each symbol represents an individual cell. $N$ values for each group are indicated on graph in parentheses. TTX-R $I_{N a}$ was detected in all EGFP-positive DRG neurons recorded (34 of 34$)$. $C, I_{N a}$-voltage relationship curves for TTX-S (O) and TTX-R (O) $I_{\text {Na }}$ recorded from EGFP-positive DRG neurons. Traces of $I_{N a}$ recorded in the presence of TTX were subtracted from traces of total $I_{N a}$ recorded before application of TTX, at the same voltages to reveal the TTX-S component of $I_{N a}$. Peak $I_{N a}$ amplitude was plotted against the voltage step used to elicit currents and normalized to maximum peak $I_{N a}$ recorded. $\boldsymbol{D}$, Voltage dependence of activation and inactivation $\left(\mathrm{h}_{\infty}\right.$-curves) for TTX-S $(\mathrm{O})$ and TTX-R $(O) I_{\mathrm{Na}}$. All voltage protocols and equations used to calculate the voltage of half-activation $\left(V_{1 / 2, \text { act }}\right)$ or half-inactivation $\left(V_{1 / 2, \text { inact }}\right)$ and slope factor (k) values are detailed in Materials and Methods.

$\left(I_{N a}\right)$ and whole-cell voltage-clamp electrophysiology, $\mathrm{Na}_{\mathrm{v}} 1.8$ protein function in EGFP-expressing DRG neurons was assessed. Both TTX-S and TTX-R $I_{\mathrm{Na}}$ were recorded from DRG neurons using a series of command pulses from a holding potential of -80 $\mathrm{mV}$ (Fig. 4A). TTX-R $I_{N a}$, or $I_{N a}$, recorded in the presence of $3 \mu \mathrm{M}$ TTX, reached its peak in $<10 \mathrm{~ms}$ and slowly decayed to a steadystate within 60 ms. TTX-S currents, derived from subtracting TTX-R $I_{N a}$ from $I_{N a}$ recorded before application of TTX, rose to a peak within $2 \mathrm{~ms}$ and decayed to baseline within $20 \mathrm{~ms}$. The proportion of TTX-R $I_{\mathrm{Na}}$ relative to total $I_{\mathrm{Na}}$ was calculated for EGFP and non-EGFP-expressing DRG neurons (Fig. 4B); and in every EGFP-expressing cell recorded, TTX-R $I_{\mathrm{Na}}$ was detected $(n=34)$. The $I-V$ relationship of peak TTX-S (gray circles) and TTX-R (white-filled circles) $I_{N a}$ is shown in Figure 4C. Maximum TTX-S $I_{N a}$ amplitude was reached at $-5 \mathrm{mV}$, whereas TTX-R $I_{N a}$ amplitude reached a maximum $10 \mathrm{mV}$ more depolarized at $5 \mathrm{mV}$. Both components of $I_{\mathrm{Na}}$ reversed near $30 \mathrm{mV}$. The voltage dependence of activation was determined by transforming the peak $I_{N a}$ versus voltage curves into conductance versus voltage $(G-V)$ curves as described in Materials and Methods. The averages of the
Table 2. Biophysical properties of TTX-S and TTX-R $I_{\mathrm{Na}}$ components of EGFP-positive DRG neurons ${ }^{a}$

\begin{tabular}{lcc}
\hline & \multicolumn{1}{c}{$\mathrm{TTX}-\mathrm{S} I_{\mathrm{Na}}$} & $\mathrm{TTX}-\mathrm{R} I_{\mathrm{Na}}$ \\
\hline$V_{1 / 2, \text { act }}(\mathrm{mV})$ & $-20.6 \pm 0.3$ & $-6.7 \pm 0.2^{*}$ \\
$k_{a}(\mathrm{mV})$ & $4.0 \pm 0.2$ & $3.7 \pm 0.2$ \\
$V_{1 / 2, \text { inact }}(\mathrm{mVV})$ & $-60.7 \pm 1.1$ & $-25.3 \pm 0.6^{*}$ \\
$k_{i}(\mathrm{mV})$ & $-8.9 \pm 0.9$ & $-6.9 \pm 0.6$ \\
\hline
\end{tabular}

${ }^{a}$ Summary of sodium channel properties of EGFP-positive DRG neurons from Scn10a-EGFP mice. TTX-R $I_{N a}$ were recorded in the presence of $3 \mu \mathrm{MTTX}$, and TTX-S $I_{N a}$ were derived from subtracting the TTX-R component of $I_{N a}$ from total $I_{\text {Nar }}$ recorded before application of TTX. All voltage protocols and equations used to calculate $V_{1 / 2}$ and $\mathrm{kvalues}$ are detailed in Materials and Methods. Complete activation curves were constructed from recordings of $28 \mathrm{EGFP}$ positive DRG neurons, and the inactivation protocol was successfully applied to 23 EGFP-positive DRG neurons. Data are mean \pm SEM.

${ }^{*} p<0.001$ (Student's $t$ test).

normalized $G-V$ curves $\left(G / G_{\max }\right)$ for TTX-R and TTX-S components are shown in Figure $4 D$. The $G-V$ curve was fit to a Boltzmann function that provides the voltage midpoint as well as slope factor of the voltage-dependent response as parameters (Table 2). The activation voltage range for TTX-S channels was $-30 \mathrm{mV}$ to $-5 \mathrm{mV}$, with a half-maximal conductance at $-21 \mathrm{mV}$. For 
TTX-R channels, the activation voltage range was $-25 \mathrm{mV}$ to 5 $\mathrm{mV}$, with a half-maximal conductance at $-6.7 \mathrm{mV}$. The voltage dependence of steady-state inactivation, or $\mathrm{h}_{\infty}$, curve, was plotted as normalized peak $I_{\mathrm{Na}}$ from the test pulse following inactivation pulses versus the voltage of the inactivating conditioning pulse (Fig. 4D) and fit to a Boltzmann function to calculate the voltage midpoint of inactivation and slope factor (Table 2). The $V_{1 / 2 \text {,inact }}$, or voltage of half-inactivation, for TTX-R channels is significantly shifted in the depolarizing direction compared with TTX-S channels (Fig. 4D; Table 2; $p<0.001$, Student's $t$ test). Thus, the properties of TTX-R $I_{N a}$ recorded from EGFP-positive DRG neurons were similar to TTX-R $I_{N a}$ recorded previously from DRG neurons and heterologously expressed $\mathrm{Na}_{\mathrm{v}} 1.8$ channels in sympathetic neurons (Akopian et al., 1999; Fjell et al., 1999a, 1999b; Schofield et al., 2008; Han et al., 2014). Overall, EGFP expression in Scn10a-EGFP mice correlates well with the presence of $\mathrm{Na}_{\mathrm{v}} 1.8$.

\section{Characterization of EGFP-expressing DRG neurons from Scn10a-EGFP mice}

Because growth factors can influence the expression of $\mathrm{Na}_{\mathrm{v}} 1.8$ (Dib-Hajj et al., 1998; Fjell et al., 1999a, b; Leffler and Cummins, 2002), expression of the EGFP transgene in the presence of growth factors was tested (Fig. 5A). The EGFP signal in DRG neurons from Scn10a-EGFP mice disappeared after $6 \mathrm{~d}$ in culture with normal medium. However, EGFP expression was detected after $6 \mathrm{~d}$ in culture with medium supplemented with GDNF or NGF. Therefore, the inserted transgene displays growth factor dependence similar to $\mathrm{Na}_{\mathrm{v}} 1.8$ channels.

To further characterize the population of DRG neurons labeled by the reporter transgene, dissociated DRG neurons from Scn10a-EGFP mice were colabeled with various markers of distinct DRG populations. IB4, from Griffonia simplicifolia, recognizes terminal $\alpha$-D-galactosyl residues and identifies nonpeptidergic unmyelinated primary afferent neurons (Stucky and Lewin, 1999). Live-cell imaging of acutely dissociated DRG neurons from an Scn10a-EGFP-positive mouse treated with IB4 conjugated to fluorescent dye is shown in Figure $5 B$. IB4 binding was detected in $35 \%$ of all DRG neurons and $>50 \%$ of EGFPexpressing DRG neurons of transgenic mice (Table 1). Indeed, $75 \%$ of IB4-positive DRG neurons in transgenic mice also expressed EGFP. A histogram of the number of cells versus cell diameter is shown in Figure 5C. EGFP-expressing DRG neurons displayed a multimodal distribution (white bars) ranging in diameter from 11 to $48 \mu \mathrm{m}$ with three distinct populations distributed around diameters of 20, 25, and $35 \mu \mathrm{m}$. IB4 binding EGFP-positive DRG neurons accounts for nearly all of the DRG neurons within the small- to medium-sized population (filled purple bars). The peptidergic population of DRG neurons expressing CGRP or Substance P was also probed in EGFP-positive DRG neurons. Although a small percentage of DRG neurons were immunoreactive positive (IR-positive) for CGRP and Substance $\mathrm{P}$ (15\% and $8 \%$, respectively), a large proportion of both peptidergic populations expressed the EGFP transgene (Table 1). Over $60 \%$ of CGRP-IR-positive and $46 \%$ of Substance P-IRpositive DRG neurons expressed EGFP in transgenic mice. The proportion of A-fiber neurons in transgenic mice expressing EGFP was probed using fluorescently tagged $\mathrm{CtB}$ and antibodies against Neurofilament 200 (NF200). Approximately 9\% of EGFP-positive neurons colabeled with markers of A-fibers and $10 \%$ of DRG neurons positive for CtB binding or NF200-IR also expressed EGFP (Table 1). So, a small population of A-fiber neurons in Scn10a-EGFP mice expressed the EGFP transgene. A sub- population of DRG neurons containing TH was examined as well. TH-IR was found in 5.6\% of EGFP-positive neurons, and $>30 \%$ of TH-IR-positive neurons expressed EGFP (Table 1). Last, almost all EGFP-expressing DRG neurons in Scn10a-EGFP mice coexpressed the voltage-gated sodium channel subtype 1.7 $\left(\mathrm{Na}_{\mathrm{v}} 1.7\right.$; Table 1$)$, a TTX-S channel commonly expressed in nociceptive DRG neurons.

\section{Lack of EGFP expression in placodal-derived sensory ganglia of Scn10a-EGFP mice}

TTX-R $I_{N a}$, with properties similar to the currents observed in this study, has been reported in cranial sensory ganglia (Ikeda et al., 1986; Cummins et al., 2002; Nakamura and Bradley, 2011). Because most of the TTX-R $I_{N a}$ in these studies was attributed to $\mathrm{Na}_{\mathrm{v}} 1.8$ channels, we expected EGFP expression in sensory neurons derived from cranial ganglia of transgenic mice similar to DRGs. However, there was a lack of EGFP expression in several cranial ganglia of Scn10a-EGFP mice. In the nodose ganglion, sparse EGFP-positive cell bodies were present at the rostral end of the ganglion (Fig. 6Ai). Only 7\% of nodose neurons in transgenic mice expressed EGFP compared with $>45 \%$ of DRG neurons (Table 1). A recent study has demonstrated fusion of neurons from the jugular ganglion into the rostral end of the nodose ganglion in mice (Nassenstein et al., 2010). Examination further rostral to the nodose ganglion of transgenic mice revealed that the jugular ganglion directly adjacent to the nodose ganglion had an abundance of bright EGFP-positive cell bodies (Fig. 6Aii). Therefore, nodose ganglia of Scn10a-EGFP mice lack transgene expression because the EGFP expression observed in the nodose ganglion may actually be EGFP-positive neurons from the jugular ganglion. To confirm the presence of $\mathrm{Na}_{\mathrm{v}} 1.8$ protein in the nodose ganglion of Scn10a-EGFP mice, immunostaining experiments using an antibody against mouse $\mathrm{Na}_{\mathrm{v}} 1.8$ was used. Thin sections of a nodose ganglion from a transgenic mouse show positive staining for $\mathrm{Na}_{\mathrm{v}} 1.8$ (Fig. 6Aiii), and $>45 \%$ of dissociated nodose ganglion neurons display $\mathrm{Na}_{\mathrm{v}} 1.8$ IR, similar to the percentage obtained from dissociated DRG neurons (Table 1).

The previously mentioned study (Nassenstein et al., 2010) differentiated jugular and nodose neurons by crossing a $\beta$-galactosidase reporter mouse with the Wnt1-Cre mouse line, which expresses Cre-recombinase in early migratory neural crest cells. Because neural crest-derived neurons, such as those from the DRG and jugular ganglia, of transgenic mice express EGFP but not placodal-derived neurons from the nodose ganglion, we examined cranial ganglia that originate from neurogenic placodes to determine whether a correlation exists between expression of our transgene and the embryological origin of neurons. Similar to the nodose ganglion, EGFP was absent in the petrosal ganglion (Fig. 6B) and geniculate ganglion (Fig. 6C). Neurons within the trigeminal ganglion have a mixed embryological origin; neurons in the distal portions of the trigeminal ganglion, which develop from the trigeminal placode, appear to have diminished EGFP expression (Fig. 6D).

To confirm that the lack of EGFP expression in placodalderived sensory ganglia is not an artifact of transgenic mouse generation (i.e., random insertion of the transgene into the genome), acute expression of the reporter construct used to develop Scn10a-EGFP mice was tested in dissociated nodose ganglion neurons. Injection of plasmid cDNA into the nucleus of neurons has been successfully used in previous studies to heterologously express proteins of interest (Ikeda, 2004) and to assay Scn10a promoter activity (Puhl and Ikeda, 2008). Because of the fused 

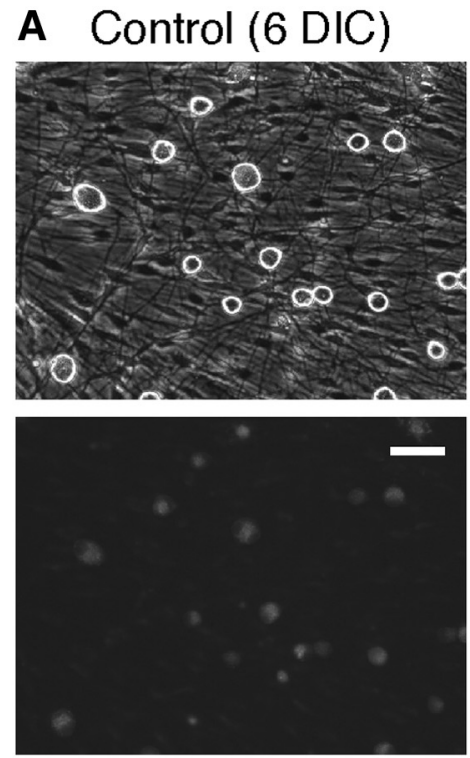

B

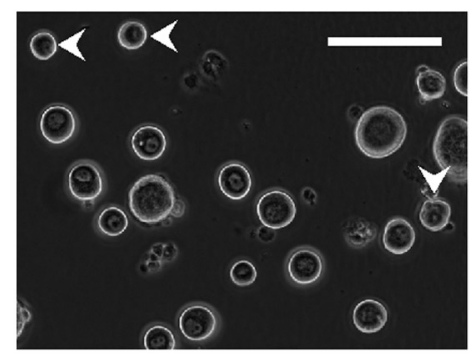

GDNF
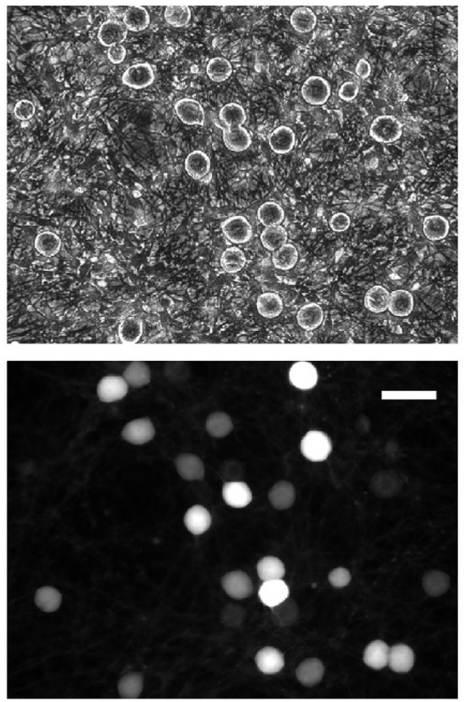

EGFP
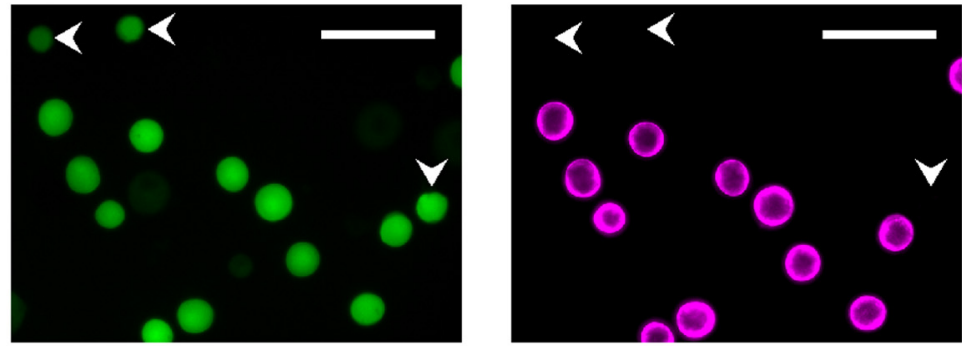

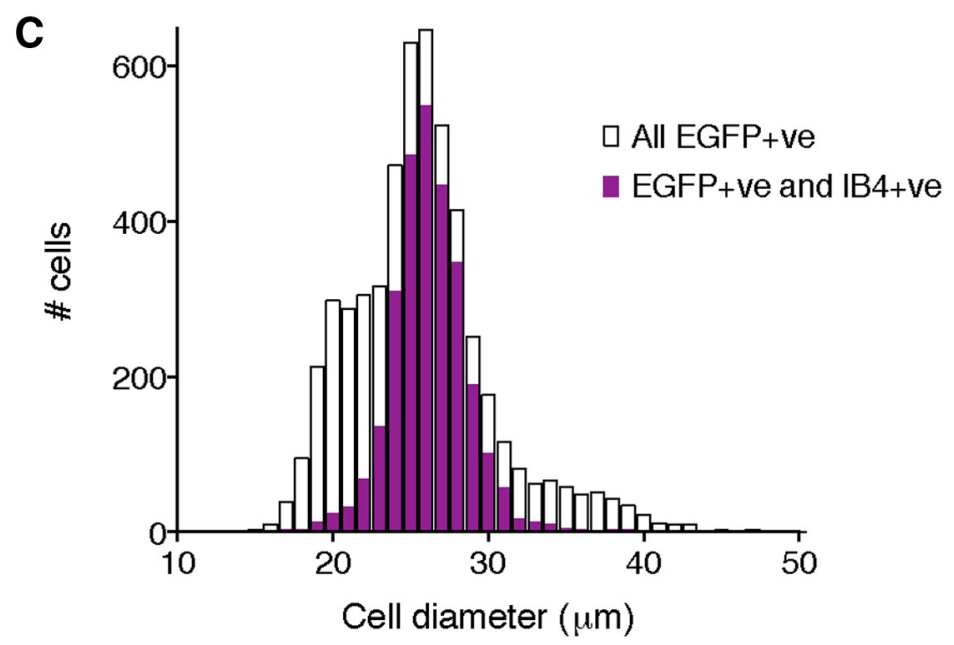

Figure 5. Characterization of EGFP-expressing DRG neurons from Scn10a-EGFP mice. $A$, Growth factor dependence of EGFP expression in DRG neurons from transgenic mice under untreated control (left), GDNF (middle), or NGF (right) conditions after $6 \mathrm{~d}$ in culture (DIC). Top, Phase-contrast images. Bottom, EGFP fluorescence images. Scale bar, $50 \mu \mathrm{m}$. $\boldsymbol{B}$, Phase-contrast (left), EGFP (middle), and red fluorescence (right) images of IB4-AlexaFluor-568-stained DRG neurons from transgenic mice. White arrowhead indicates EGFP-positive DRG neurons not bound to IB4. Scale bar, $50 \mu \mathrm{m}$. C, Distribution of EGFP-positive DRG neurons from Scn10a-EGFP mice (white bars). Purple-filled bars indicate EGFP-positive DRG neurons that were also IB4-positive. The IB4-positive population accounts for a large proportion of small- to medium-sized EGFP-positive neurons.

jugular-nodose ganglia complex in mice, rat nodose and DRG neurons were injected with a plasmid construct consisting of the putative Scn10a promoter and EGFP gene, along with dsRed2nuc cDNA, to identify successfully injected neurons (Fig. 6Ei). Almost $40 \%$ of injected rat DRG neurons expressed EGFP, but $<5 \%$ of injected rat nodose ganglion neurons ex- pressed EGFP, which is statistically significant (Fig. 6Eii; $p<$ 0.001 , Fisher's exact test). Similar percentages of EGFPpositive neurons were observed from the dissociated ganglia of transgenic animals. Thus, our inserted transgene construct failed to report $S c n 10 a$ expression in placodal-derived sensory ganglia. 
$\mathbf{A}_{\mathrm{i}}$

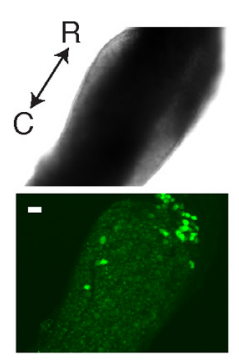

ii

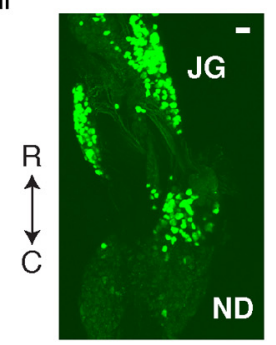

iii

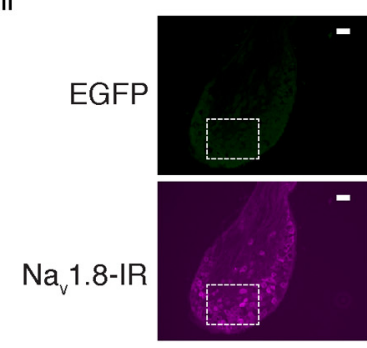

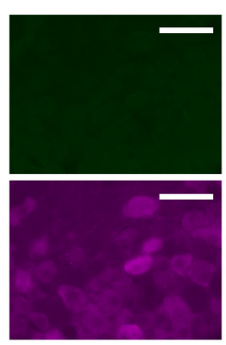

B

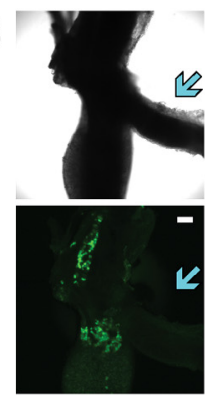

E

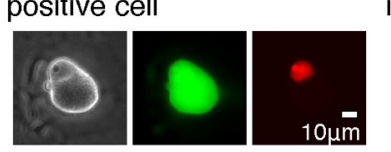

ii

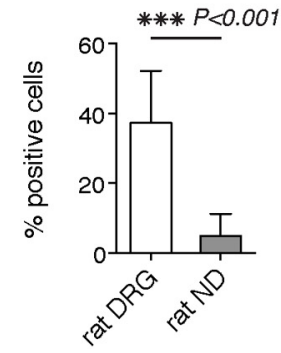

Figure 6. Lack of EGFP expression in placodal-derived ganglia from Scn10a-EGFP mice. A, Nodose ganglia. Ai, Phase-contrast (top) and EGFP fluorescence (bottom) images of the same nodose ganglion. EGFP fluorescence was predominantly at the rostral end of the nodose ganglion. Arrow indicates the rostral (R)-caudal (C) orientation. Aii, Fluorescence image of the jugular-nodose ganglion complex from an Scn10a-EGFP mouse. JG, Jugular ganglion. Aiii, Immunohistochemistry of a sectioned nodose ganglion. Lower-magnification images are on the left; higher-magnification images are on the right. There is no EGFP fluorescence in the nodose section (top) but an abundance of $\mathrm{Na}_{\mathrm{v}} 1.8-\mathrm{IR}$ (bottom). $\boldsymbol{B}-\boldsymbol{D}$, Top, Bright-field images. Bottom, EGFP fluorescence images. $\boldsymbol{B}$, Petrosal ganglion, indicated by blue arrow. $\boldsymbol{C}$, Geniculate ganglion, indicated by blue arrow. $\boldsymbol{D}$, Trigeminal ganglion, distal portion indicated by blue arrow. $\boldsymbol{E}$, Summary of nuclear injection experiments with primary rat neurons and plasmid construct consisting of the putative $S c n 10$ a promoter and EGFP gene. Ei, Sample images of positive (above) or negative (below) neuron for SCn10a promoter-EGFP construct expression. Positive marker for successful nuclear injections, dsRed2nuc, shown on the right. Eii, The number of positive cells, expressed as a percentage of total neurons injected, and 95\% confidence intervals are represented on graph. A total of 46 rat DRG neurons (from 4 different animals) and 103 rat nodose neurons (from 5 different animals) were injected. The proportion of injected neurons expressing EGFP was significantly different between both groups. ${ }^{* *} p<0.001$ (Fisher's exact test). Unless otherwise stated: scale bar, $50 \mu \mathrm{m}$.

\section{EGFP expression outside of the nervous system of Scn10a-EGFP mice}

The expression of $\mathrm{Na}_{\mathrm{v}} 1.8$ is highly restricted to peripheral sensory ganglia neurons. However, recent reports suggest expression of $\mathrm{Na}_{\mathrm{v}} 1.8$ outside of the nervous system. We therefore investigated the presence of EGFP in these regions and tested for possible ectopic EGFP expression.

EGFP-positive cells were observed within transverse sections of cardiac tissues of Scn10a-EGFP mice (Fig. 7Ai). Positive cells were found in fat pads at the base of the aorta and pulmonary artery, in an area corresponding to the cardiac ganglion. Although $\mathrm{Na}_{\mathrm{v}} 1.8$-IR is found in human cardiomyocytes (Facer et al., 2011), we did not observe EGFP expression in the myocardium of transgenic mice (Fig. 7Aii).

A recent study suggests the presence of $\mathrm{Na}_{\mathrm{v}} 1.8$ in human testes (Cejudo-Roman et al., 2013) and retina (O'Brien et al., 2008); however, we did not observe a EGFP signal or EGFP immunoreactivity (EGFP-IR) in the testes (Fig. $7 B$ ) or eyes (Fig. $7 C$ ) of transgenic mice. Various tissues from Scn10a-EGFP mice were also probed with an antibody against EGFP, and a weak positive signal was observed in the pancreas (Fig. 7D) and kidney (Fig. $7 E$ ). No EGFP expression was detected in the spleen, liver, lung, small and large intestine, or stomach of Scn10a-EGFP mice (data not shown).

A bright EGFP signal was observed from the footpads of EGFP-positive mice but not wild-type littermates (Fig. 7Fi). EGFP expression was bright enough to observe under fluorescence microscopy without amplification by immunostaining procedures. The majority of the EGFP signal emanated from the superficial layers of the epidermis (Fig. 7Fiii), not the peripheral afferent terminal fibers mentioned previously (Fig. $1 E$ ). It is unlikely EGFP expression in the outer skin layers reflects functional expression of $\mathrm{Na}_{\mathrm{v}} 1.8$ channels because the superficial epidermis consists of dead, keratinized cells without a cytoplasm or nucleus. EGFP expression in the outer skin layers may reflect ectopic transgene activation as a result of epithelium differentiation, which involves a massive upregulation of transcription factors (for review, see Fuchs, 1990). Interestingly, one of these transcription factors may regulate Scn10a expression. Moreover, this bright superficial EGFP signal could prove to be a convenient alternative to genotyping for the identification of transgenic positive mice.

An EGFP signal was also visible in the nose of genotypepositive mice (Fig. $7 G$ ), which was most visible in young pups ( $<3 \mathrm{~d}$ old). The Grueneberg ganglion, an olfactory organ capable of detecting alarm pheromones and cold temperatures (Mamasuew et al., 2008; Fleischer and Breer, 2010; Schmid et al., 2010), is located within the nasal cavity, and dissection of this ganglion revealed EGFP expression (Fig. $7 G$, right). The ability of $\mathrm{Na}_{\mathrm{v}} 1.8$ channels to transmit electrical impulses at low temperatures (Zimmermann et al., 2007), which aligns with the cold-sensing function of the Grueneberg ganglion, and the presence of TTX-R $I_{\mathrm{Na}}$ from Grueneberg ganglion cells (Liu et al., 2012) supports the presence of $\mathrm{Na}_{\mathrm{v}} 1.8$ expression in the Grueneberg ganglion.

\section{EGFP expression in the CNS of Scn10a-EGFP mice}

EGFP expression was examined in the brains of transgenic mice as well (Fig. 8A). The basolateral amygdala contained a number of EGFP-positive cells. Cells expressing EGFP were also found in the brainstem, in a cluster of cells close to the spinal nucleus of the trigeminal nerve and sparsely distributed cell bodies in the medulla oblongata. Unlike Gautron et al. (2011), no EGFP signal was observed in the nucleus of the solitary tract likely because of the lack of EGFP transgene expression in the nodose ganglion (Fig. 6A). EGFP-expressing cells were distributed throughout the 
A i cardiac ganglion

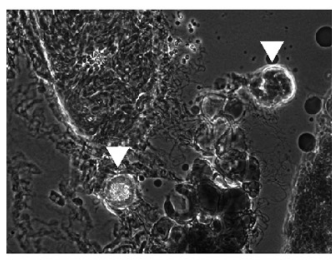

B testes

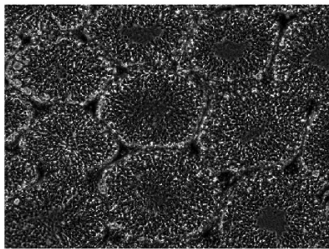

D pancreas
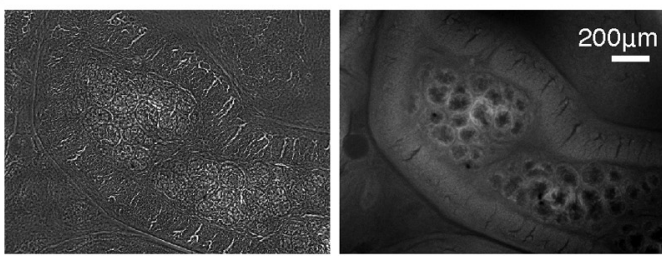

F i

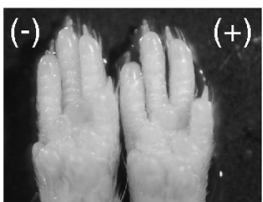

ii
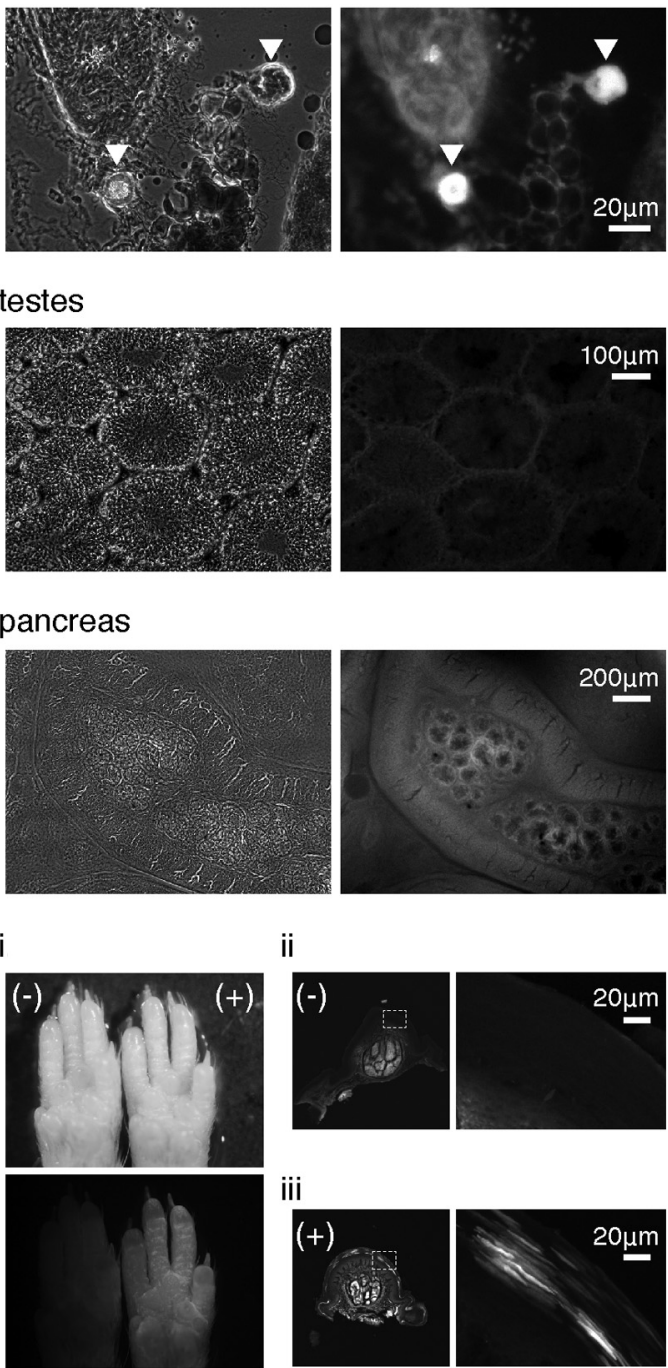

ii cardiac muscle
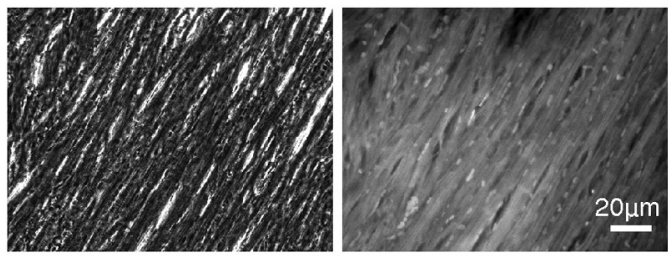

C eye
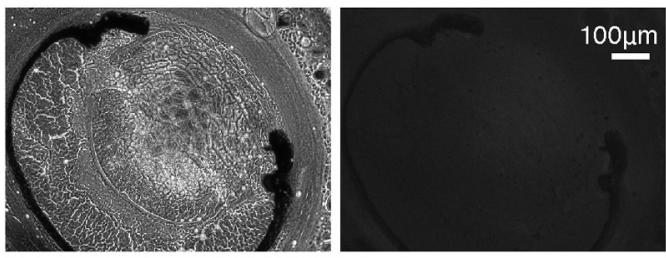

E kidney
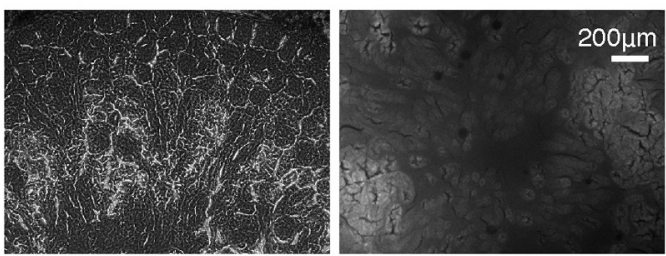

G
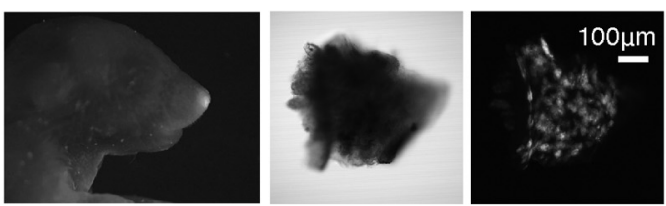

Figure 7. EGFP expression outside the nervous system of $S \boldsymbol{C n} 10 a$-EGFP mice. $\boldsymbol{A}-\boldsymbol{E}$, Left, Phase-contrast images. Right, EGFP fluorescence images. $\boldsymbol{A}$, Images from transverse sections of cardiac ganglion (Ai) or cardiac muscle (Aii) tissue. White arrowheads indicate EGFP-positive cells in both images. $\boldsymbol{B}$, Testes. $\boldsymbol{C}$, Eye. D, Pancreas. $\boldsymbol{E}$, Kidney. F, Ectopic EGFP expression in epidermal skin layers. Fi, Paw on the left from a wild-type mouse; paw on the right from an EGFP-positive transgenic mouse. Fii, Thin footpad skin section from a wild-type mouse. Fiii, Thin footpad skin section from an EGFP-positive transgenic mouse. G, Grueneberg ganglion. Left, Low-magnification fluorescence image of an Scn10a-EGFP mouse nose. Phase-contrast (middle) and EGFP fluorescence (right) image of a dissected Grueneberg ganglion from an Scn10a-EGFP mouse under higher magnification.

somatosensory cortex, but not in the primary motor cortex, and only a sparse number of bright EGFP-positive cells were found in the globus pallidus. The largest and brightest cluster of EGFPpositive cells was observed in the olfactory tubercle and hypothalamus, particularly in the rostral end, or peduncular part, of the lateral hypothalamus and paraventricular nucleus. IHC staining using antibodies against EGFP and $\mathrm{Na}_{\mathrm{v}} 1.8$ protein confirmed EGFP expression in discrete brain regions and revealed cell bodies positive for both proteins (Fig. 8A). However, not all EGFPpositive cells were coimmunoreactive to $\mathrm{Na}_{\mathrm{v}} 1.8$. In addition, low EGFP-IR was observed in the mitral cell layer of the olfactory bulb, periaqueductal gray, and islands of Calleja in the ventral striatum but did not correlate with $\mathrm{Na}_{\mathrm{v}} 1.8$-IR (data not shown).

To corroborate IHC results, $\mathrm{Na}_{\mathrm{v}} 1.8$ transcript was probed in tissue samples from Scn10a-EGFP mice. Scn10a and control $\beta$-actin transcripts were amplified by conventional RT-PCR to produce amplicons 742 and 500 bp in size, respectively, and resolved using agarose gel electrophoresis. Faint bands, corresponding to the predicted size of the Scn10a amplicon, were observed for amygdala, brainstem, somatosensory cortex, hypothalamus, olfactory tubercle, and superior cervical ganglion (SCG) tissue samples compared with a dense band in the DRG sample lane (Fig. $8 B$ ). A band corresponding to the $\beta$-actin amplicon was observed with all tissue samples tested. No bands were detected in DRG tissue amplified without reverse transcriptase and the no template negative control (W, water). Quantitative PCR analysis of a panel of brain and peripheral tissues was performed to assess the relative abundance of Scn10a transcript. The level of Scn10a transcript was highest in DRG tissues (Fig. 8C). nodose tissue samples also expressed an abundant amount of Scn10a transcript similar to DRG samples. Transcript was detected, although significantly less, in amygdala, brainstem, globus pallidus, hypothalamus, olfactory tubercle, and SCG tissue samples $(p<0.01$, one-way ANOVA with Holm-Sidak's multiplecomparisons test). Two samples of the globus pallidus and one sample of SCG tissue did not produce amplification curves and were excluded from analysis. Also, no amplification curves were observed for primary motor cortex, somatosensory cortex, hip- 


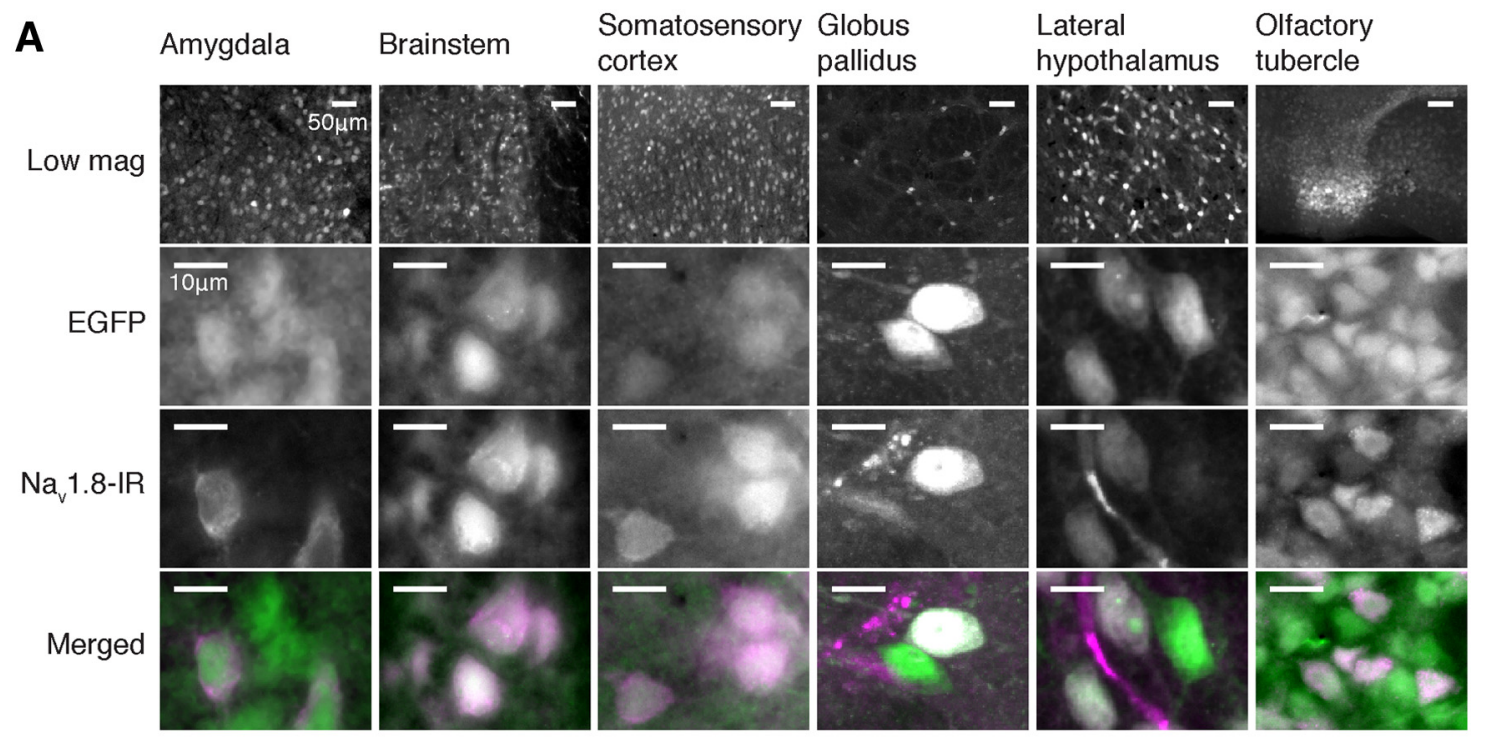

B
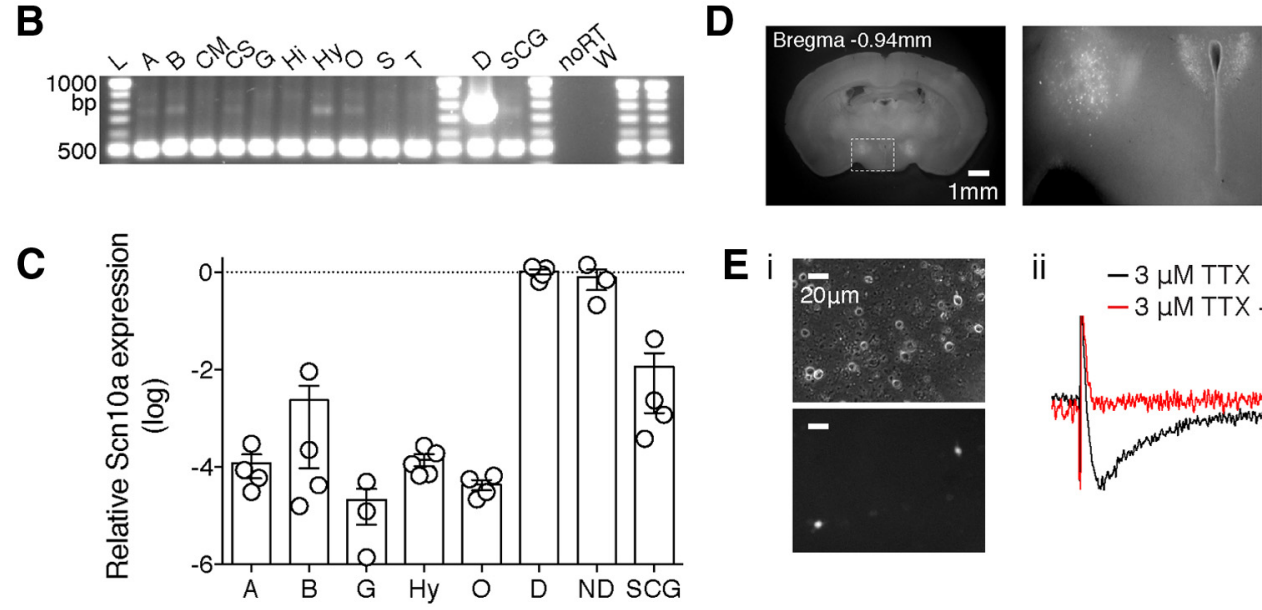

ii $\quad-3 \mu \mathrm{M}$ TTX

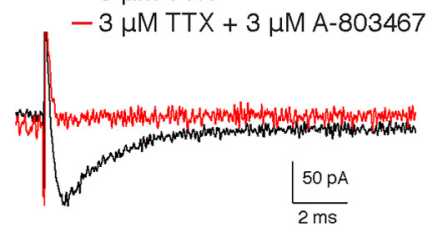

Figure 8. EGFP expression in discrete regions of the CNS of SCn10a-EGFP mice. $A$, IHC of various brain regions. First row panels represent low-magnification ( $20 \times / 0.30 \mathrm{NA}$ objective) fluorescence images obtained from the EGFP channel. Scale bar, $50 \mu \mathrm{m}$. Remaining images are higher-magnification (63×/1.2 NA objective) fluorescent images from the EGFP channel (second row), red channel (third row), or merged images from both fluorescence channels pseudo-colored green and purple (fourth row). Scale bar, $10 \mu \mathrm{m}$ for images obtained at higher magnification. $\boldsymbol{B}$, Conventional RT-PCR analysis of mRNA encoding $S \mathrm{Cn} 10 a$ and $\beta$-actin in multiple brain regions and peripheral ganglia. Based on the primer sets used, the predicted sizes of the $S \mathrm{c} n 10 a$ and $\beta$-actin amplicons are 742 and 500 bp, respectively. The resultant PCR products were separated and visualized on a $1.5 \%$ agarose gel. $A$, Amygdala; $B$, brainstem; $C M$, primary motor cortex; $C S$, somatosensory cortex; $G$, globus pallidus; Hi, hippocampus; Hy, hypothalamus; 0, olfactory tubercle; S, striatum; T, thalamus; D, DRG; SCG, superior cervical ganglia; ND, nodose ganglia; W, water; L, ladder. C, Expression of $S \mathrm{~S}$ 10a transcript across various brain regions and peripheral ganglia as assessed by qPCR. Relative expression of Scn10a mRNA to DRG tissue was obtained from the formula $2^{-\Delta \Delta \mathrm{Ct}}$ (detailed in Materials and Methods). Dotted line indicates mean normalized expression level in DRG neurons $\left(2^{-\Delta \Delta \mathrm{ct}}=1\right)$. Each point indicates a biological replicate. Means are represented as bars. Error bars indicate SEM. The differences between mean $2^{-\Delta \Delta \mathrm{Ct}}$ values for all regions with DRGs were statistically significant, except for nodose $(p<0.01$, one-way ANOVA with Holm-Sidak's multiplecomparisons test). D, Acutely prepared coronal brain slice under fluorescence optics. Hypothalamic region magnified to the right. Ei, Acutely dissociated hypothalamic neurons under phase-contrast (above) or EGFP fluorescence (below). Eii, Sample electrophysiological recording from an EGFP-positive dissociated hypothalamic neuron. Black trace represents $I_{N a}$ recorded in the presence of $3 \mu \mathrm{M}$ TTX. Red trace represents $I_{N a}$ recorded in the presence of $3 \mu \mathrm{m}$ TTX and $3 \mu \mathrm{m}$ A-803467 drug. Four consecutive current traces for each condition were averaged and represented.

pocampus, striatum, and thalamus samples as well as no reverse transcriptase and no template-negative controls. The presence of Scn10a mRNA in SCG samples was confirmed in both transcript assays, which was surprising because TTX-R $I_{N a}$ have not been observed in dissociated rat SCG neurons (Schofield and Ikeda, 1988). However, the close proximity of SCGs to petrosal and nodose ganglia, both sensory ganglia that express $\mathrm{Na}_{\mathrm{v}} 1.8$, in mice may facilitate fusion during development and lead to inadvertent contamination of SCG samples.

As mentioned previously, the EGFP fluorescence from cells in the hypothalamus was bright enough to be visible in acutely prepared brain slices (300 $\mu \mathrm{m}$ thick; Fig. $8 D$ ), thus allowing identification of acutely dissociated neurons for electrophysiological study (Fig. $8 \mathrm{Ei}$ ). In 8 of 22 EGFP-positive hypothalamic neurons,
$I_{\mathrm{Na}}$ were recorded in the presence of $3 \mu \mathrm{M}$ TTX (mean TTX-R $I_{\mathrm{Na}}$ amplitude $=-37.6 \pm 7.2 \mathrm{pA}, n=8$ ), which could be blocked by the $\mathrm{Na}_{\mathrm{v}} 1.8$ selective blocker A-803467 ( $3 \mu \mathrm{M}$, 4 of 4 cells tested; Fig. 8Eii). A-803467 also blocks low voltage-activated $\mathrm{Ca}^{2+}$ channels (Bladen and Zamponi, 2012); however, we are fairly confident the currents blocked in dissociated hypothalamic neurons are from $\mathrm{Na}_{\mathrm{v}} 1.8$ channels for two reasons. First, our external recording solution contained $\mathrm{Mg}^{2+}(10 \mathrm{~mm})$, which is impermeant and blocks inward currents carried by monovalent cations through voltage-gated $\mathrm{Ca}^{2+}$ channels (Fukushima and Hagiwara, 1985). Second, the concentration of A-803467 used $(3 \mu \mathrm{M})$ was near the plateau for $100 \%$ inhibition of TTX-R $I_{\mathrm{Na}}$ (Jarvis et al., 2007) but is approximately the $\mathrm{IC}_{50}$ for A-803467 block of low voltage-activated $I_{\mathrm{Ca}}$. We observed complete block of TTX-R $I_{\mathrm{Na}}$ 
in dissociated hypothalamic neurons tested with $3 \mu \mathrm{M} \mathrm{A-803467}$ (Fig. 8Eii).

To our knowledge, this is the first demonstration of TTX-R $I_{\mathrm{Na}}$ recordings from central neurons thought to arise from $\mathrm{Na}_{\mathrm{v}}$ 1.8. As the TTX-R $I_{\mathrm{Na}}$ recorded from EGFP-positive hypothalamic neurons of transgenic mice accounted for only $1.6 \pm 0.3 \%$ $(n=8)$ of the total $I_{N a}$ it seems unlikely that $\mathrm{Na}_{\mathrm{v}} 1.8$ channels make a major contribution to normal neuronal activity in these neurons. However, the role of $\mathrm{Na}_{\mathrm{v}} 1.8$ in CNS excitability may be larger under pathological conditions. Other studies have demonstrated upregulated $\mathrm{Na}_{\mathrm{v}} 1.8$-IR in cerebellar Purkinje neurons of patients diagnosed with multiple sclerosis (Shields et al., 2012b) and in an animal model of multiple sclerosis (Black et al., 2000; Damarjian et al., 2004).

\section{Discussion}

We have previously identified a fragment of genomic DNA upstream of the Scn10a gene, which drives EGFP reporter expression in a subpopulation of DRG neurons within primary cultures but not in select cell lines or sympathetic and central neurons (Puhl and Ikeda, 2008). This reporter construct has been used by others to identify putative nociceptive neurons in rat DRG preparations for further study (Hassan and Ruiz-Velasco, 2013; Hassan et al., 2014). Here, we characterize a transgenic mouse line generated from this same reporter cassette that confirms and expands our previous in vitro findings. An Scn10a reporter mouse line, such as the one detailed in this study, will allow identification of the $\mathrm{Na}_{\mathrm{v}} 1.8$-expressing population of sensory neurons. Furthermore, our transgenic reporter mouse is amendable to functional studies, as it does not involve inactivation of the Scn10a gene, and offers temporal resolution of $\mathrm{Na}_{\mathrm{v}} 1.8$ expression unavailable in Cre-recombinase-based reporter systems.

Characterization of any transgenic line is very important for their utility. Hence, we carefully investigated the EGFP transgenic reporter expression pattern and its correlation with Scn10a message and gene product, $\mathrm{Na}_{\mathrm{v}} 1.8$. The expression of $\mathrm{Na}_{\mathrm{v}} 1.8$ channels is mainly restricted to primary sensory neurons, and in Scn10a-EGFP mice, EGFP expression was most prominent in a subset of DRG neuron somata (Fig. 1B). The majority of EGFPpositive cells were small- to medium-sized, nonpeptidergic neurons that bound IB4 (Fig. 5B,C; Table 1), whereas a small proportion $(8 \%-10 \%)$ were medium- to large-diameter myelinated A-fiber neurons as denoted by colabeling with $\mathrm{CtB}$ and NF200 (Table 1). This result is in agreement with other studies characterizing the $\mathrm{Na}_{\mathrm{v}} 1.8$-expressing population of DRG neurons in rats (Amaya et al., 2000; Ramachandra et al., 2013) and $\mathrm{Na}_{\mathrm{v}} 1.8$-Cre mice (Agarwal et al., 2004; Shields et al., 2012a). A population of small-diameter DRG neurons also expressed EGFP, including a fraction that colabeled with markers of peptidergic neurons, CGRP and Substance P, and TH. Recent work suggests that TH is exclusively expressed in a population of unmyelinated low-threshold mechanoreceptor C-fiber neurons (Usoskin et al., 2015), and this population of neurons is responsive to cold stimuli (Seal et al., 2009). Interestingly, $\mathrm{Na}_{\mathrm{v}} 1.8$ channels are the only voltage-gated sodium channels that remain functional at cold temperatures and are responsible for action potential generation in response to noxious cold (Zimmermann et al., 2007). EGFP expression in the outer and inner Lamina II of the spinal dorsal horn, where IB4 binding and low-threshold mechanoreceptor C-fibers, respectively, terminate, supports $\mathrm{Na}_{\mathrm{v}} 1.8$ expression in these DRG neuronal populations.

Expression of EGFP in DRG neurons of transgenic mice correlated well with the presence of $\mathrm{Na}_{\mathrm{v}} 1.8$ transcript (Figs. 2, 8C) and protein (Fig. 3; Table 1). In terms of functional $\mathrm{Na}_{\mathrm{v}} 1.8$ protein, EGFP-positive DRG neurons from transgenic mice display sodium currents in the presence of TTX with kinetic and biophysical properties similar to those attributed to $\mathrm{Na}_{\mathrm{v}} 1.8$ channels (Fig. 4; Table 2). TTX-R $I_{N a}$ have been described in C-type sensory neurons as well as in some $\mathrm{A} \delta$ and high-threshold $\mathrm{A} \beta$ neurons (Shields et al., 2012a; Ramachandra et al., 2013). Glial cell-derived neurotrophic factor and nerve growth factor maintains EGFP expression in DRG neurons of Scn10a-EGFP mice (Fig. 5A), which is consistent with the influence growth factors have on the magnitude of TTX-R $I_{N a}$ in DRG neurons (Fjell et al., 1999a, b; Leffler and Cummins, 2002). The correlation between EGFP expression and $\mathrm{Na}_{\mathrm{v}} 1.8$-IR was high ( $80 \%$ of $\mathrm{Na}_{\mathrm{v}} 1.8$-IR cells were also EGFP-positive) but not absolute. Overall, the Scn10aEGFP mice generated and characterized in this study serve as a good reporter of $\mathrm{Na}_{\mathrm{v}} 1.8$ expression in peripheral sensory neurons. The promoter region we previously identified and validated in vitro (Puhl and Ikeda, 2008) recapitulates most $\mathrm{Na}_{\mathrm{v}} 1.8$ expression in vivo.

Failure of EGFP expression in $\mathrm{Na}_{\mathrm{v}} 1.8$ expressing cells (i.e., false negatives) might suggest the involvement of other promoter elements beyond the $3.7 \mathrm{~kb}$ genomic fragment used to generate transgenic mice. Further supporting this notion, several cranial sensory ganglia in Scn10a-EGFP mice failed to express EGFP (Fig. $6 A-D)$. Neuronal cell bodies within the caudal portion of the nodose ganglion lacked an EGFP signal (Fig. 6A) despite expressing $\mathrm{Na}_{\mathrm{v}} 1.8$ transcript (Fig. $8 C$ ) and protein (Fig. 6Aii; Table 1). Moreover, EGFP was absent in the nucleus of the solitary tract and area postrema, brainstem regions that receive inputs from visceral afferents originating from nodose ganglion neurons. This lack of reporter gene expression was in contrast to findings from the $\mathrm{Na}_{\mathrm{v}} 1.8$-Cre reporter mouse (Gautron et al., 2011) and was not a positional artifact of transgenic mouse generation (i.e., random insertion into genome) because acute expression of the same transgene construct recapitulated the absence of transgene expression in dissociated rat nodose neurons (Fig. $6 E$ ). In contrast, the jugular ganglion, located immediately rostral to the nodose ganglion, expressed an abundance of EGFP in neuronal cell bodies (Fig. 6Aii). The jugular ganglion, which forms a fused complex with the nodose ganglion in mice, develops from the neural crest as opposed to the nodose ganglion, which arises from epibranchial placodes. A reporter mouse line that labels neurons originating from the neural crest (Wnt1-Cre) exhibits a similar pattern of expression as EGFP in the jugular-nodose ganglia complex of our transgenic mice (Nassenstein et al., 2010), thus supporting our conclusion that the $3.7 \mathrm{~kb}$ promoter fragment chosen to generate transgenic mice directs Scn10a expression in neural crest but not placodal-derived sensory ganglion neurons.

We previously described two promoter modules within the $3.7 \mathrm{~kb}$ promoter fragment used here. Both modules, a proximal neuron specific module and a distal sensory neuron restrictive module, are required to produce the highly restrictive expression pattern of Scn10a. Elimination of the distal module alleviates the sensory neuron restrictive expression of Scn10a to allow reporter expression in peripheral sympathetic neurons and a neuroblastoma cell line (Puhl and Ikeda, 2008). Based on our current study, the mechanism restricting transgene expression in neural crestderived neurons of transgenic mice appears to involve these two modules; however, additional elements or modules may be necessary to expand endogenous Scn10a expression in placodalderived neurons. This idea is not without precedence as a similar promoter organization has been found for the rat TH gene. In that case, a proximal $4.5 \mathrm{~kb}$ promoter region drove expression in 
CNS neurons and an additional $4.5 \mathrm{~kb}$ distal region upstream expanded expression and directed a more canonical expression pattern in central and peripheral sympathetic catecholaminergic neurons (Schimmel et al., 1999; Gelman et al., 2003).

Alternatively, a second promoter for the Scn10a gene responsible for expression in placodal-derived neurons is also possible. The Scn5a gene, a genomic neighbor of the Scn10a gene that encodes the TTX-R voltage-gated sodium channel $\mathrm{Na}_{\mathrm{v}} 1.5$, has been shown to contain multiple promoters operating at distinct developmental stages (Shang and Dudley, 2005). Identification of the specific promoter or additional promoter elements responsible for Scn10a expression in placodal-derived neurons may be useful in selectively targeting cranial neurons responsible for gustatory and viscerosensory functions rather than neurons that convey somatosensory information. We are also using the Scn10a-EGFP mouse as a tool to identify neural crest-specific proteins or transcription factors that may be responsible for the restrictive expression pattern of $\mathrm{Na}_{\mathrm{v}} 1.8$ in peripheral sensory neurons. Studies into additional promoter regions or promoter elements of the Scn10a gene are ongoing.

In summary, we have extended our previous in vitro characterization of a $3.7 \mathrm{~kb}$ promoter region controlling expression of the Scn10a gene by creating a transgenic mouse line. Our main findings include the following: (1) The incorporation of the 3.7 $\mathrm{kb}$ reporter cassette supported our previous findings of expression in a subset of sensory neurons of the DRG and a lack of expression in sympathetic neurons. (2) The $3.7 \mathrm{~kb}$ genomic region produced selective reporter expression in neurons of neural crest-derived sensory ganglia but not in sensory neurons from ganglia of placodal decent. (3) In addition to these main findings, we have also documented reporter expression in a variety of novel peripheral and central locations and used this reporter expression to isolate some of these neurons for further studies. These experiments have not only shown coincidental expression of Scn10a transcript with reporter EGFP but have also allowed for the functional identification of the TTX-R $I_{\mathrm{Na}}$ in these neurons, thus exemplifying the utility of this reporter mouse line as a tool to study expression of $\mathrm{Na}_{\mathrm{v}} 1.8$ in select locations. Expanding upon this idea, these mice may also serve as a valuable resource to facilitate the identification and hence the study of nociceptive neurons as well as the effects of various environmental and pathological states on the expression of the transgene and therefore the Scn10a gene.

\section{References}

Abrahamsen B, Zhao J, Asante CO, Cendan CM, Marsh S, Martinez-Barbera JP, Nassar MA, Dickenson AH, Wood JN (2008) The cell and molecular basis of mechanical, cold, and inflammatory pain. Science 321:702-705. CrossRef Medline

Agarwal N, Offermanns S, Kuner R (2004) Conditional gene deletion in primary nociceptive neurons of trigeminal ganglia and dorsal root ganglia. Genesis 38:122-129. CrossRef Medline

Akopian AN, Souslova V, England S, Okuse K, Ogata N, Ure J, Smith A, Kerr BJ, McMahon SB, Boyce S, Hill R, Stanfa LC, Dickenson AH, Wood JN (1999) The tetrodotoxin-resistant sodium channel SNS has a specialized function in pain pathways. Nat Neurosci 2:541-548. CrossRef Medline

Amaya F, Decosterd I, Samad TA, Plumpton C, Tate S, Mannion RJ, Costigan M, Woolf CJ (2000) Diversity of expression of the sensory neuronspecific TTX-resistant voltage-gated sodium ion channels SNS and SNS2. Mol Cell Neurosci 15:331-342. CrossRef Medline

Black JA, Dib-Hajj S, Baker D, Newcombe J, Cuzner ML, Waxman SG (2000) Sensory neuron-specific sodium channel SNS is abnormally expressed in the brains of mice with experimental allergic encephalomyelitis and humans with multiple sclerosis. Proc Natl Acad Sci U S A 97:11598-11602. CrossRef Medline

Bladen C, Zamponi GW (2012) Common mechanisms of drug interactions with sodium and T-type calcium channels. Mol Pharmacol 82:481-487. CrossRef Medline

Catterall WA (2000) From ionic currents to molecular mechanisms: the structure and function of voltage-gated sodium channels. Neuron 26:13-25. CrossRef Medline

Cejudo-Roman A, Pinto FM, Subirán N, Ravina CG, Fernández-Sánchez M, Pérez-Hernández N, Pérez R, Pacheco A, Irazusta J, Candenas L (2013) The voltage-gated sodium channel $\mathrm{Na}_{\mathrm{v}} 1.8$ is expressed in human sperm. PLoS One 8:e76084. CrossRef Medline

Cummins TR, Dib-Hajj SD, Waxman SG, Donnelly DF (2002) Characterization and developmental changes of $\mathrm{Na}^{+}$currents of petrosal neurons with projections to the carotid body. J Neurophysiol 88:2993-3002. CrossRef Medline

Damarjian TG, Craner MJ, Black JA, Waxman SG (2004) Upregulation and colocalization of p75 and $\mathrm{Na}_{\mathrm{v}} 1.8$ in Purkinje neurons in experimental autoimmune encephalomyelitis. Neurosci Lett 369:186-190. CrossRef Medline

Dib-Hajj SD, Black JA, Cummins TR, Kenney AM, Kocsis JD, Waxman SG (1998) Rescue of alpha-SNS sodium channel expression in small dorsal root ganglion neurons after axotomy by nerve growth factor in vivo. J Neurophysiol 79:2668-2676. Medline

Djouhri L, Fang X, Okuse K, Wood JN, Berry CM, Lawson SN (2003) The TTX-resistant sodium channel $\mathrm{Na}_{\mathrm{v}} 1.8$ (SNS/PN3): expression and correlation with membrane properties in rat nociceptive primary afferent neurons. J Physiol 550:739-752. CrossRef Medline

Edelstein A, Amodaj N, Hoover K, Vale R, Stuurman N (2010) Computer control of microscopes using $\mu$ Manager. Curr Protoc Mol Biol 92: 14.20.1-14.20.17. CrossRef Medline

Facer P, Punjabi PP, Abrari A, Kaba RA, Severs NJ, Chambers J, Kooner JS, Anand P (2011) Localisation of SCN10A gene product $\mathrm{Na}_{\mathrm{v}} 1.8$ and novel pain-related ion channels in human heart. Int Heart J 52:146-152. CrossRef Medline

Fjell J, Cummins TR, Dib-Hajj SD, Fried K, Black JA, Waxman SG (1999a) Differential role of GDNF and NGF in the maintenance of two TTXresistant sodium channels in adult DRG neurons. Mol Brain Res 67:267282. CrossRef Medline

Fjell J, Cummins TR, Fried K, Black JA, Waxman SG (1999b) In vivo NGF deprivation reduces SNS expression and TTX-R sodium currents in IB4negative DRG neurons. J Neurophysiol 81:803-810. Medline

Fleischer J, Breer H (2010) The Grueneberg ganglion: a novel sensory system in the nose. Histol Histopathol 25:909-915. Medline

Fuchs E (1990) Epidermal differentiation: the bare essentials. J Cell Biol 111:2807-2814. CrossRef Medline

Fukushima Y, Hagiwara S (1985) Currents carried by monovalent cations through calcium channels in mouse neoplastic B lymphocytes. J Physiol 358:255-284. CrossRef Medline

Gautron L, Sakata I, Udit S, Zigman JM, Wood JN, Elmquist JK (2011) Genetic tracing of $\mathrm{Na}_{\mathrm{v}} 1.8$-expressing vagal afferents in the mouse. J Comp Neurol 519:3085-3101. CrossRef Medline

Gelman DM, Noaín D, Avale ME, Otero V, Low MJ, Rubinstein M (2003) Transgenic mice engineered to target Cre/loxP-mediated DNA recombination into catecholaminergic neurons. Genesis 36:196-202. CrossRef Medline

Hamill OP, Marty A, Neher E, Sakmann B, Sigworth FJ (1981) Improved patch-clamp techniques for high-resolution current recording from cells and cell-free membrane patches. Pflugers Arch 391:85-100. CrossRef Medline

Han C, Vasylyev D, Macala LJ, Gerrits MM, Hoeijmakers JG, Bekelaar KJ, Dib-Hajj SD, Faber CG, Merkies IS, Waxman SG (2014) The G1662S $\mathrm{Na}_{\mathrm{V}} 1.8$ mutation in small fibre neuropathy: impaired inactivation underlying DRG neuron hyperexcitability. J Neurol Neurosurg Psychiatry 85: 499-505. CrossRef Medline

Hassan B, Ruiz-Velasco V (2013) The $\kappa$-opioid receptor agonist U-50488 blocks $\mathrm{Ca}^{2+}$ channels in a voltage- and $\mathrm{G}$ protein-independent manner in sensory neurons. Reg Anesth Pain Med 38:21-27. CrossRef Medline

Hassan B, Kim JS, Farrag M, Kaufman MP, Ruiz-Velasco V (2014) Alteration of the mu opioid receptor: $\mathrm{Ca}^{2+}$ channel signaling pathway in a subset of rat sensory neurons following chronic femoral artery occlusion. J Neurophysiol 112:3104-3115. CrossRef Medline

Ikeda SR (2004) Expression of G-protein signaling components in adult mammalian neurons by microinjection. Methods Mol Biol 259:167-181. CrossRef Medline 
Ikeda SR, Schofield GG, Weight FF (1986) $\mathrm{Na}^{+}$and $\mathrm{Ca}^{2+}$ currents of acutely isolated adult rat nodose ganglion cells. J Neurophysiol 55:527539. Medline

Jarvis MF, Honore P, Shieh CC, Chapman M, Joshi S, Zhang XF, Kort M, Carroll W, Marron B, Atkinson R, Thomas J, Liu D, Krambis M, Liu Y, McGaraughty S, Chu K, Roeloffs R, Zhong C, Mikusa JP, Hernandez G, et al. (2007) A-803467, a potent and selective $\mathrm{Na}_{\mathrm{v}} 1.8$ sodium channel blocker, attenuates neuropathic and inflammatory pain in the rat. Proc Natl Acad Sci U S A 104:8520-8525. CrossRef Medline

Leffler A, Cummins T, Dib-Hajj SD, Hormuzdiar WN, Black JA, Waxman SG (2002) GDNF and NGF reverse changes in repriming of TTX-sensitive $\mathrm{Na}^{+}$currents following axotomy of dorsal root ganglion neurons. J Neurophysiol 88:650-658. Medline

Liu CY, Xiao C, Fraser SE, Lester HA, Koos DS (2012) Electrophysiological characterization of Grueneberg ganglion olfactory neurons: spontaneous firing, sodium conductance, and hyperpolarization-activated currents. J Neurophysiol 108:1318-1334. CrossRef Medline

Lu VB, Williams DJ, Won YJ, Ikeda SR (2009) Intranuclear microinjection of DNA into dissociated adult mammalian neurons. J Vis Exp 34:pii1614. CrossRef Medline

Mamasuew K, Breer H, Fleischer J (2008) Grueneberg ganglion neurons respond to cool ambient temperatures. Eur J Neurosci 28:1775-1785. CrossRef Medline

Nakamura S, Bradley RM (2011) Characteristics of sodium currents in rat geniculate ganglion neurons. J Neurophysiol 106:2982-2991. CrossRef Medline

Nassar MA, Stirling LC, Forlani G, Baker MD, Matthews EA, Dickenson AH, Wood JN (2004) Nociceptor-specific gene deletion reveals a major role for $\mathrm{Na}_{\mathrm{v}} 1.7$ (PN1) in acute and inflammatory pain. Proc Natl Acad Sci U S A 101:12706-12711. CrossRef Medline

Nassar MA, Levato A, Stirling LC, Wood JN (2005) Neuropathic pain develops normally in mice lacking both $\mathrm{Na}_{\mathrm{v}} 1.7$ and $\mathrm{Na}_{\mathrm{v}} 1.8$. Mol Pain 1:24. CrossRef Medline

Nassenstein C, Taylor-Clark TE, Myers AC, Ru F, Nandigama R, Bettner W, Undem BJ (2010) Phenotypic distinctions between neural crest and placodal derived vagal C-fibres in mouse lungs. J Physiol 588:4769-4783. CrossRef Medline

O’Brien BJ, Caldwell JH, Ehring GR, Bumsted O’Brien KM, Luo S, Levinson SR (2008) Tetrodotoxin-resistant voltage-gated sodium channels $\mathrm{Na}_{\mathrm{v}} 1.8$ and $\mathrm{Na}_{\mathrm{v}} 1.9$ are expressed in the retina. J Comp Neurol 508:940951. CrossRef Medline

Puhl HL 3rd, Ikeda SR (2008) Identification of the sensory neuron specific regulatory region for the mouse gene encoding the voltage-gated sodium channel $\mathrm{Na}_{\mathrm{V}}$ 1.8. J Neurochem 106:1209-1224. CrossRef Medline
Ramachandra R, McGrew SY, Baxter JC, Howard JR, Elmslie KS (2013) $\mathrm{Na}_{\mathrm{V}} 1.8$ channels are expressed in large, as well as small, diameter sensory afferent neurons. Channels (Austin) 7:34-37. CrossRef Medline

Schimmel JJ, Crews L, Roffler-Tarlov S, Chikaraishi DM (1999) $4.5 \mathrm{~kb}$ of the rat tyrosine hydroxylase $5^{\prime}$ flanking sequence directs tissue specific expression during development and contains consensus sites for multiple transcription factors. Mol Brain Res 74:1-14. CrossRef Medline

Schmid A, Pyrski M, Biel M, Leinders-Zufall T, Zufall F (2010) Grueneberg ganglion neurons are finely tuned cold sensors. J Neurosci 30:7563-7568. CrossRef Medline

Schmittgen TD, Livak KJ (2008) Analyzing real-time PCR data by comparative C(T) method. Nat Protoc 3:1101-1108. Medline

Schofield GG, Ikeda SR (1988) Sodium and calcium currents of acutely isolated adult rat superior cervical ganglion neurons. Pflugers Arch 411:481490. CrossRef Medline

Schofield GG, Puhl HL 3rd, Ikeda SR (2008) Properties of wild-type and fluorescent protein-tagged mouse tetrodotoxin-resistant sodium channel $\left(\mathrm{Na}_{\mathrm{V}} 1.8\right)$ heterologously expressed in rat sympathetic neurons. J Neurophysiol 99:1917-1927. CrossRef Medline

Seal RP, Wang X, Guan Y, Raja SN, Woodbury CJ, Basbaum AI, Edwards RH (2009) Injury-induced mechanical hypersensitivity requires C-low threshold mechanoreceptors. Nature 462:651-655. CrossRef Medline

Shang LL, Dudley SC Jr (2005) Tandem promoters and developmentally regulated $5^{\prime}$ - and $3^{\prime}$-mRNA untranslated regions of the mouse Scn5a cardiac sodium channel. J Biol Chem 280:933-940. CrossRef Medline

Shields SD, Ahn HS, Yang Y, Han C, Seal RP, Wood JN, Waxman SG, DibHajj SD (2012a) $\mathrm{Na}_{\mathrm{v}} 1.8$ expression is not restricted to nociceptors in mouse peripheral nervous system. Pain 153:2017-2030. CrossRef Medline

Shields SD, Cheng X, Gasser A, Saab CY, Tyrrell L, Eastman EM, Iwata M, Zwinger PJ, Black JA, Dib-Hajj SD, Waxman SG (2012b) A channelopathy contributes to cerebellar dysfunction in a model of multiple sclerosis. Ann Neurol 71:186-194. CrossRef Medline

Stucky CL, Lewin GR (1999) Isolectin B4-positive and -negative nociceptors are functionally distinct. J Neurosci 19:6497-6505. Medline

Usoskin D, Furlan A, Islam S, Abdo H, Lönnerberg P, Lou D, Hjerling-Leffler J, Haeggström J, Kharchenko O, Kharchenko P, Linnarsson S, Ernfors P (2015) Unbiased classification of sensory neuron types by large-scale single-cell RNA sequencing. Nat Neurosci:145-153. CrossRef Medline

Zimmermann K, Leffler A, Babes A, Cendan CM, Carr RW, Kobayashi J, Nau C, Wood JN, Reeh PW (2007) Sensory neuron sodium channel $\mathrm{Na}_{\mathrm{v}} 1.8$ is essential for pain at low temperatures. Nature 447:855-858. CrossRef Medline 